\title{
New constraints on terrestrial and oceanic sources of atmospheric methanol
}

\author{
D. B. Millet ${ }^{1, *}$, D. J. Jacob ${ }^{1}$, T. G. Custer ${ }^{2}$, J. A. de Gouw ${ }^{3}$, A. H. Goldstein ${ }^{4}$, T. Karl ${ }^{5}$, H. B. Singh ${ }^{6}$, B. C. Sive ${ }^{7}$, \\ R. W. Talbot ${ }^{7}$, C. Warneke ${ }^{3}$, and J. Williams ${ }^{2}$ \\ ${ }^{1}$ Harvard University, Department of Earth and Planetary Sciences and School of Engineering and Applied Sciences, \\ Cambridge, Massachusetts, USA \\ ${ }^{2}$ Max Planck Institute for Chemistry, Mainz, Germany \\ ${ }^{3}$ NOAA ESRL, Chemical Sciences Division, Boulder, Colorado, USA \\ ${ }^{4}$ UC Berkeley, Department of Environmental Science, Policy and Management, Berkeley, California, USA \\ ${ }^{5}$ NCAR, Atmospheric Chemistry Division, Boulder, Colorado, USA \\ ${ }^{6}$ NASA Ames Research Center, Moffett Field, California, USA \\ ${ }^{7}$ University of New Hampshire, Climate Change Research Center, Durham, New Hampshire, USA \\ *now at: University of Minnesota, Department of Soil, Water and Climate, St. Paul, Minnesota, USA
}

Received: 31 January 2008 - Published in Atmos. Chem. Phys. Discuss.: 17 April 2008

Revised: 22 September 2008 - Accepted: 13 October 2008 - Published: 1 December 2008

\begin{abstract}
We use a global 3-D chemical transport model (GEOS-Chem) to interpret new aircraft, surface, and oceanic observations of methanol in terms of the constraints that they place on the atmospheric methanol budget. Recent measurements of methanol concentrations in the ocean mixed layer (OML) imply that in situ biological production must be the main methanol source in the OML, dominating over uptake from the atmosphere. It follows that oceanic emission and uptake must be viewed as independent terms in the atmospheric methanol budget. We deduce that the marine biosphere is a large primary source $\left(85 \mathrm{Tg} \mathrm{a}^{-1}\right)$ of methanol to the atmosphere and is also a large sink $\left(101 \mathrm{Tg} \mathrm{a}^{-1}\right)$, comparable in magnitude to atmospheric oxidation by $\mathrm{OH}$ $\left(88 \mathrm{Tg} \mathrm{a}^{-1}\right)$. The resulting atmospheric lifetime of methanol in the model is 4.7 days. Aircraft measurements in the North American boundary layer imply that terrestrial plants are a much weaker source than presently thought, likely reflecting an overestimate of broadleaf tree emissions, and this is also generally consistent with surface measurements. We deduce a terrestrial plant source of $80 \mathrm{Tg} \mathrm{a}^{-1}$, comparable in magnitude to the ocean source. The aircraft measurements show a strong correlation with $\mathrm{CO}\left(R^{2}=0.51-0.61\right)$ over North
\end{abstract}

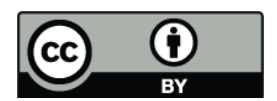

Correspondence to: D. B. Millet (dbm@umn.edu)
America during summer. We reproduce this correlation and slope in the model with the reduced plant source, which also confirms that the anthropogenic source of methanol must be small. Our reduced plant source also provides a better simulation of methanol observations over tropical South America.

\section{Introduction and background}

Methanol is the most abundant non-methane organic gas in the atmosphere. It is a significant global source of tropospheric CO (Duncan et al., 2007) and formaldehyde (Millet et al., 2006a), and plays a minor role in the tropical $\mathrm{HO}_{\mathrm{x}}$ and ozone budgets (Tie et al., 2003). The atmospheric methanol budget is uncertain, with estimates of the global source ranging from 123 to $343 \mathrm{Tg} \mathrm{a}^{-1}$ (Tie et al., 2003; von Kuhlmann et al., 2003a, b; Jacob et al., 2005). Aircraft and surface measurements from recent field experiments provide new constraints on methanol sources and sinks. Here we use a global 3-D chemical transport model (GEOS-Chem CTM) to interpret these datasets in terms of their implications for the atmospheric methanol budget.

Plant growth accounts for $40-80 \%$ of total emissions of methanol to the atmosphere according to literature estimates (Singh et al., 2000; Galbally and Kirstine, 2002; Heikes et al., 2002; Tie et al., 2003; von Kuhlmann et al., 2003a;

Published by Copernicus Publications on behalf of the European Geosciences Union. 
Jacob et al., 2005). We will argue here that current estimates of this source are too high and that the marine biosphere is of comparable importance. Other methanol sources include biomass burning (e.g. McKenzie et al., 1994; Holzinger et al., 1999; Goode et al., 2000; Bertschi et al., 2003; Christian et al., 2003; Yokelson et al., 2003; Sinha et al., 2004; Greenberg et al., 2006), atmospheric production via peroxy radical reactions (Madronich and Calvert, 1990; Tyndall et al., 2001), decaying plant matter (Warneke et al., 1999; Schade and Custer, 2004; Karl et al., 2005a), and urban/industrial activities (e.g. Olivier et al., 1994).

The principal sink for atmospheric methanol appears to be photochemical oxidation by the hydroxyl radical $(\mathrm{OH})$, which takes place on a timescale of $\sim 10$ days. Other important sinks include dry deposition to land (Karl et al., 2004; Jacob et al., 2005; Karl et al., 2005b; Talbot et al., 2005; Mao et al., 2006) and ocean uptake (Heikes et al., 2002; Singh et al., 2003; Carpenter et al., 2004; Williams et al., 2004; Mao et al., 2006; Sinha et al., 2007). Tabazadeh et al. (2004) proposed that aqueous-phase aerosol chemistry could be a major sink for methanol, but this does not appear to be supported by atmospheric observations (Jacob et al., 2005). Previous analyses of the global methanol budget have inferred an overall atmospheric lifetime of 5-12 days (Galbally and Kirstine, 2002; Heikes et al., 2002; Tie et al., 2003; Jacob et al., 2005).

Recent ground, ship, and aircraft measurements provide new information to test and improve our understanding of atmospheric methanol. In particular, the INTEX-A and ITCT-2K4 (collectively ICARTT), INTEX-B, MILAGRO, TEXAQS-II, and ITCT-2K2 aircraft campaigns included extensive boundary layer mapping and vertical profiling over North America and the adjacent oceans. We apply here these datasets to develop new constraints on methanol emissions from terrestrial plants and on the relative importance of biogenic vs. anthropogenic sources. We focus primarily on North America because of the density of observations, but we also show that our revised source estimates significantly improve the simulation in the tropics. The first measurements of methanol in the surface ocean were reported by Williams et al. (2004); we will show that these suggest a major role for the marine biosphere in the global budget.

\section{Model description}

\subsection{GEOS-Chem}

The atmospheric distribution of methanol was simulated for 2004 using the GEOS-Chem global 3-D CTM (Bey et al., 2001; Millet et al., 2008). We used GEOS-Chem version 7.03 (http://www-as.harvard.edu/chemistry/trop/geos/ index.html) with GEOS-4 assimilated meteorological data from the NASA Goddard Earth Observing System including winds, convective mass fluxes, mixing depths, temperature, precipitation, and surface properties. The GEOS-4 data have 6-h temporal resolution (3-h for surface variables and mixing depths), $1^{\circ} \times 1.25^{\circ}$ horizontal resolution, and 55 vertical layers. We degrade the horizontal resolution to $2^{\circ} \times 2.5^{\circ}$ for input to GEOS-Chem and use a 1-year spinup to remove the effect of initial conditions. We use separate tracers to track methanol from plant growth, plant decay, urban emissions, photochemical production, ocean emissions, biomass burning, and biofuel. We chose to focus on 2004 to match the timing of the INTEX-A and ITCT-2K4 aircraft campaigns (Fehsenfeld et al., 2006; Singh et al., 2006) which are particularly valuable for our analysis. We will also compare the model to observations taken in different years, with the expectation that interannual variability is small relative to other sources of model error.

The methanol simulation presented here builds on that of Jacob et al. (2005). In the following sections we summarize the model treatment of sources and sinks and elaborate on our improved treatment of terrestrial biogenic emissions, airsea exchange, urban/industrial emissions, and dry deposition. As we will see, air-sea exchange needs to be viewed as the superimposition of independent source and sink processes, and this provides a significant change of perspective in the definition of the methanol budget.

In addition to methanol, we will use here a GEOS-Chem global simulation of $\mathrm{CO}$ to derive combustion and anthropogenic emissions of methanol from methanol/CO emission factors, and to compare observed atmospheric methanol-CO correlations to the model simulation. The GEOS-Chem CO simulation is as described by Duncan et al. (2007), but we decrease here the US anthropogenic source by $60 \%$ relative to the 1999 National Emission Inventory (NEI 99) following Hudman et al. (2008) in order to fit the ICARTT CO observations. This adjustment is supported by other work showing that NEI 99 estimates of the urban CO source in the US are too high (Parrish, 2006; Warneke et al., 2006; Hudman et al., 2008).

\subsection{Methanol sources}

\subsubsection{Plant growth source}

Most plants produce methanol, which is thought to be released as a by-product of pectin demethylation during leaf growth (Fall and Benson, 1996). The higher emission rates observed for young leaves fit with this hypothesis (Macdonald and Fall, 1993). Emissions are both temperature and light dependent, and go to zero at night (a consequence of stomatal control rather than any direct link to photosynthesis) (Nemecek-Marshall et al., 1995). Plants can also metabolize methanol, as can methylotrophic bacteria (common inhabitants of leaves and soil), so that net biogenic emissions reflect a balance between production, metabolism, and bacterial consumption on leaf surfaces (Fall and Benson, 1996). Galbally and Kirstine (2002) recommend a net emission rate equal to $0.11 \%$ of net primary production (NPP) for 

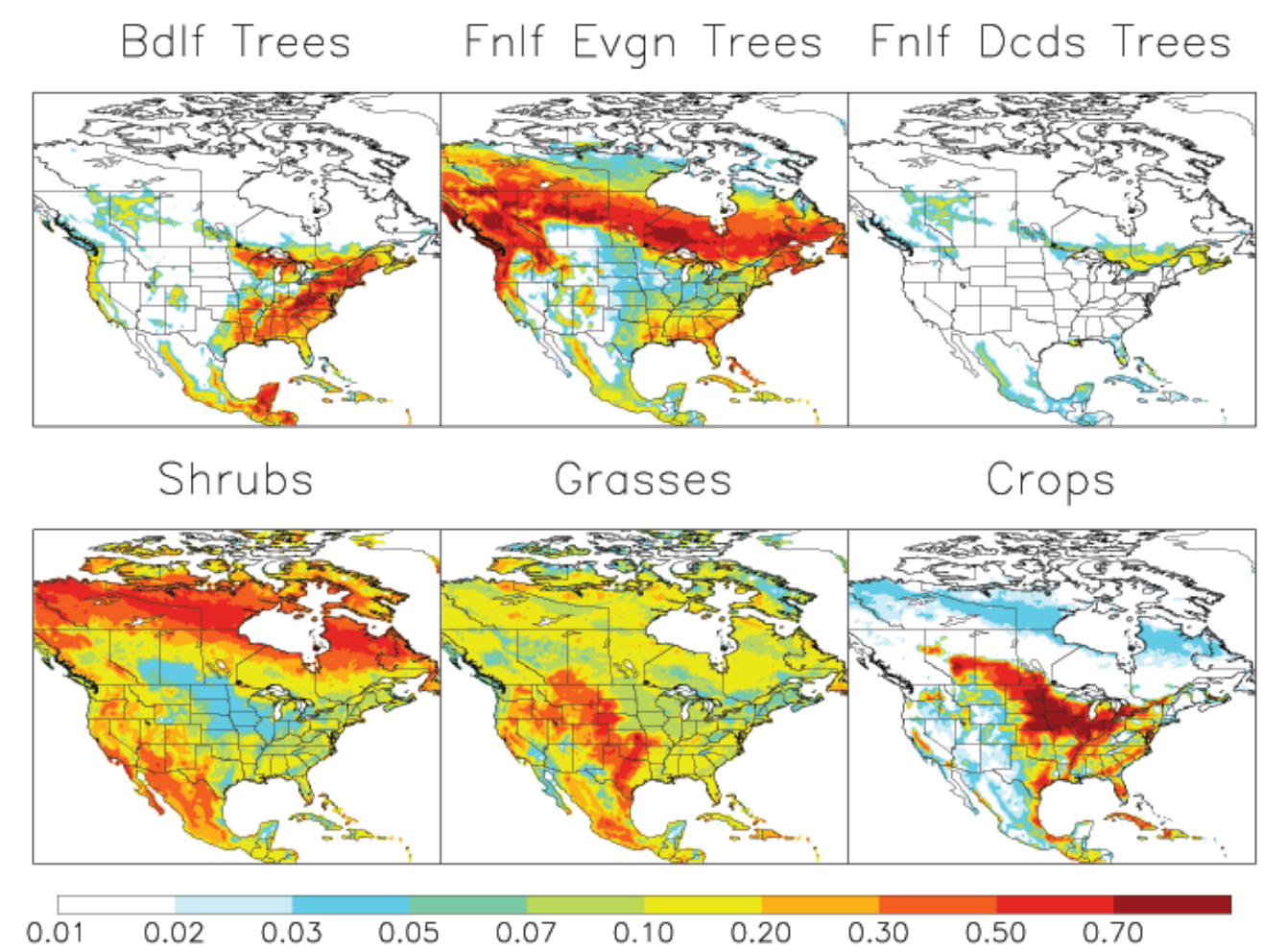

Fig. 1. Fractional distribution of plant functional types (PFTs) over North America according to the MEGAN Driving Variables Dataset v.2 (MDVD2): broadleaf trees (Bdlf Trees), fineleaf evergreen trees (Fnlf Evgn Trees), fineleaf deciduous trees (Fnlf Dcds Trees), shrubs, grasses and crops.

all vegetation types except $0.02 \%$ for grasses. We use that here as our base-case for evaluation with observations, and from there further explore the dependence of methanol emission on plant functional type (PFT).

We estimate the fractional coverage of PFTs (grasses, broadleaf trees, fineleaf evergreen trees, fineleaf deciduous trees, shrubs, and crops) within each model grid square using the MEGAN Driving Variables Database v.2 (MDVD2) (Guenther et al., 2006). The MDVD2 PFT fractions integrate the percentage vegetation coverage and type (woody vs. herbaceous) at $500 \mathrm{~m}$ resolution from MODIS (Hansen et al., 2003) with leaf longevity (evergreen vs. deciduous) and leaf type (broadleaf vs. needleleaf) from the $1 \mathrm{~km}$ AVHRRderived University of Maryland tree cover dataset (DeFries et al., 2000). Relative abundance of the non-tree PFTs is determined from ground survey information where available and the Olson et al. (2001) ecoregion database elsewhere. The AVHRR-based broadleaf and needleleaf PFT fractions in the United States are adjusted using ground survey information compiled by Kinnee et al. (1997). Figure 1 shows the MDVD2 PFT fractions over North America, which we will use below to interpret the model methanol simulation in comparison to atmospheric measurements.

Methanol emission rates are calculated for each GEOSChem model grid square by combining monthly NPP fields from the CASA 2 biosphere model (Potter et al., 1993; Randerson et al., 1997) with fractional PFT coverage from MDVD2 and the Galbally and Kirstine (2002) scaling factors. Methanol emission $E$ from a model grid square is then given by

$E=\gamma \times \operatorname{NPP} \sum_{i=1}^{6} \varepsilon_{i} \chi_{i}$,

where the sum is over all PFTs with fractional areal coverage $\chi_{i}$ and NPP scaling factors $\varepsilon_{i}$. In the base case following Galbally and Kirstine (2002), $\varepsilon_{i}=0.02 \%$ for grasses and $0.11 \%$ for other PFTs. The monthly activity factor $\gamma$ adjusts for the effect of leaf age on emissions. Here we improve upon the work of Jacob et al. (2005) by explicitly considering emissions from new, young, mature, and old leaves in each model grid square, following the MEGAN algorithm for isoprene emission (Guenther et al., 2006):

$\gamma=\beta \sum_{l=1}^{4} F_{l} A_{l}$,

with $\gamma$ determined by the fractions $(F)$ and relative emission rates $(A)$ for the four leaf age classes $l(1=$ new, $2=$ young, 

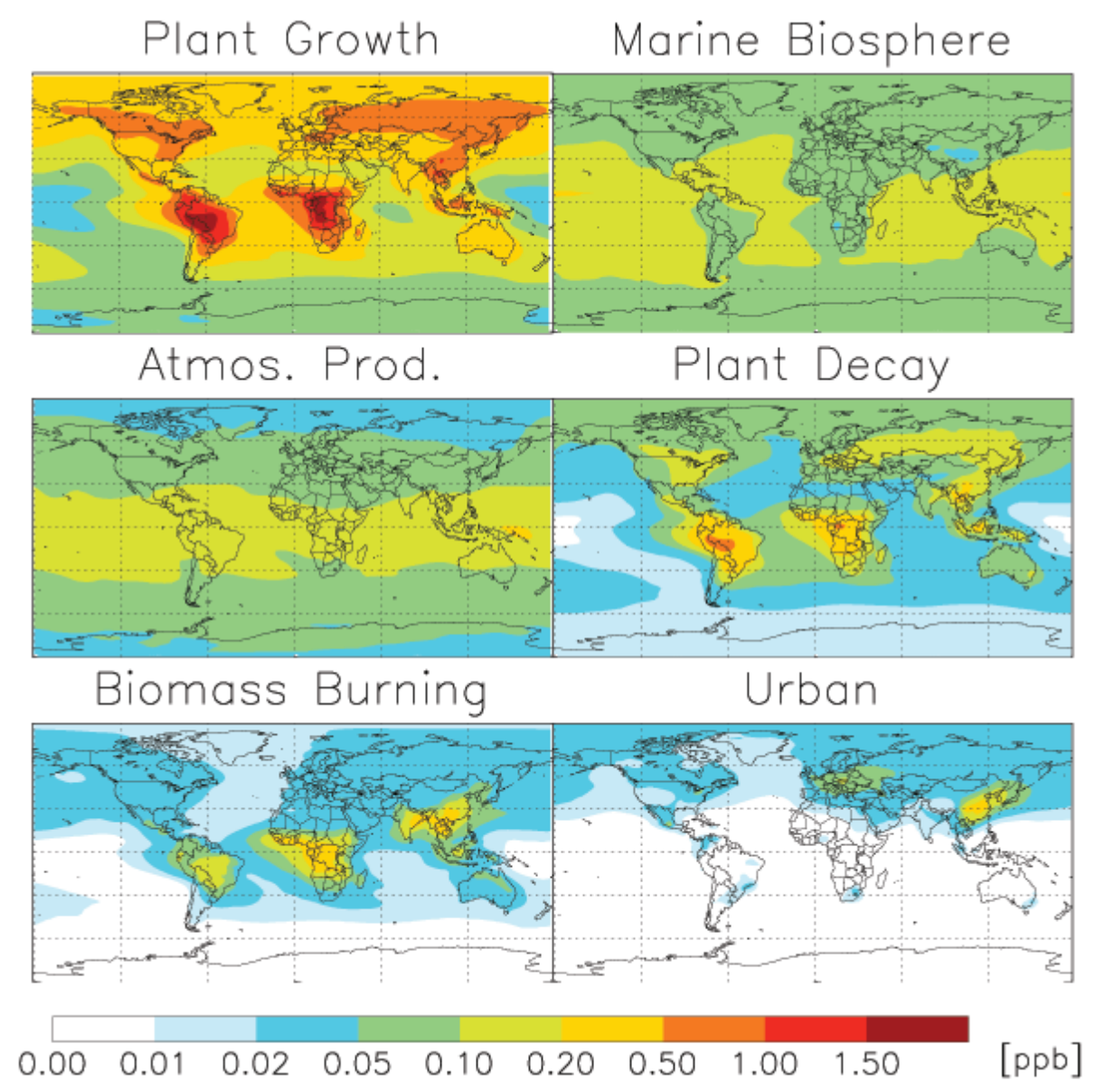

Fig. 2. Annual mean methanol column mixing ratios for the GEOS-Chem optimized (B1Cp25) simulation. Shown are contributions from terrestrial plant growth, the marine biosphere, atmospheric production, plant decay, biomass burning+biofuel emissions, and urban/industrial emissions. Global source magnitudes are given in Table 2.

$3=$ mature, $4=0$ old). $\beta$ is a scaling factor ensuring local consistency with the Galbally and Kirstine (2002) parameterization on an annual basis. We set the relative emission rate for new and young leaves to be three times that of mature leaves, which in turn is twice that of old leaves $\left(A_{1}=A_{2}=3 A_{3}=6 A_{4}\right)$ (Macdonald and Fall, 1993; Nemecek-Marshall et al., 1995). The leaf age fractions are estimated from local leaf area index (LAI) and temperature changes according to Guenther et al. (2006).

As part of this work we will derive improved methanol emission factors $\varepsilon_{i}$ on the basis of model comparisons to atmospheric observations. We show below that aircraft and surface measurements over North America imply total plant growth emissions $40-50 \%$ lower than result from the Galbally and Kirstine (2002) recommendation. The correction appears specific to broadleaf trees and crops, and we will present results from two optimized simulations: one (referred to as Biog50) with the $\varepsilon_{i}$ reduced by a factor of two for all PFTs, and one (B1Cp25) with the emission factors for broadleaf trees and crops reduced by a factor of four (other
PFTs are left at their base rate). We will see that both yield more realistic methanol concentrations over North America and the tropics than the base-case. Figure 2 shows the tropospheric column mixing ratio of methanol emitted from live foliage (annual mean) according to the second of these optimized simulations. Elevated concentrations ( $>2 \mathrm{ppb}$ ) are seen over the continental tropics, and over much of the Northern Hemisphere during summer. Our resulting best estimate for the global source is $80 \mathrm{Tg} \mathrm{a}^{-1}$, compared to $145 \mathrm{Tg} \mathrm{a}^{-1}$ for the base-case simulation.

In addition to these optimized simulations, we also attempted to reduce the model bias by replacing the NPPbased emission scheme with one based on the MEGAN biogenic emission model (Alex Guenther, personal communication). MEGAN includes spatially varying baseline emission rates and accounts for the temperature dependence of methanol emissions explicitly (emissions scaled as $\exp [\beta$ (T-303)], with $\beta=0.09$ ) rather than implicitly via its effect on NPP. This did not improve the simulation relative to atmospheric observations, and we present here results from the 
NPP-based approach as they are more straightforward to interpret in terms of the underlying vegetation.

\subsubsection{Other sources}

The oceanic source of methanol will be discussed independently in Sect. 2.4. Other methanol sources include atmospheric production, plant decay, biomass and biofuel burning, and urban and industrial emissions. Atmospheric production occurs by reaction of the methylperoxy radical with itself and with other organic peroxy radicals (Madronich and Calvert, 1990; Tyndall et al., 2001):

$$
\begin{aligned}
\mathrm{CH}_{3} \mathrm{O}_{2}+\mathrm{CH}_{3} \mathrm{O}_{2} & \rightarrow \mathrm{CH}_{3} \mathrm{O}+\mathrm{CH}_{3} \mathrm{O}+\mathrm{O}_{2} \\
& \rightarrow \mathrm{CH}_{3} \mathrm{OH}+\mathrm{HCHO}+\mathrm{O}_{2} \\
\mathrm{CH}_{3} \mathrm{O}_{2}+\mathrm{RO}_{2} & \rightarrow \mathrm{CH}_{3} \mathrm{O}+\mathrm{RO}+\mathrm{O}_{2} \\
& \rightarrow \mathrm{CH}_{3} \mathrm{OH}+\mathrm{R}^{\prime} \mathrm{CHO}+\mathrm{O}_{2}
\end{aligned}
$$

Here we use the most recent recommendations for the (R1) rate constant $\left(k_{1}=k_{1 a}+k_{1 b}=9.5 \times 10^{-14} \exp (390 / \mathrm{T})\right)$ (Sander et al., 2006) and the branching ratio between (R1a) and (R1b) $\left(k_{1 a} / k_{1 b}=26.2 \exp (-1130 / \mathrm{T})\right)$ (Tyndall et al., 2001). Following Madronich and Calvert (1990) and Jacob et al. (2005) we assume a 0.5 molar yield of methanol for all (R2) reactions. These reactions represent only minor $(<10 \%)$ sinks for $\mathrm{CH}_{3} \mathrm{O}_{2}$ and $\mathrm{RO}_{2}$ radicals (reactions with $\mathrm{NO}$ and $\mathrm{HO}_{2}$ are more important), but provide an important source of methanol in the remote atmosphere (totaling $37 \mathrm{Tg} \mathrm{a}^{-1}$ globally; Fig. 2). Jacob et al. (2005) suggested that the atmospheric source of methanol might be higher, in the range 50$100 \mathrm{Tg} \mathrm{a}^{-1}$, to explain methanol observations over the South Pacific, but it is not clear what the associated mechanism would be.

Methanol is also produced biotically and abiotically from dead and decaying plants. Along with in-leaf methanol that gets released after the plant dies, additional methanol is thought to be produced from the demethylation of pectin in cell walls via the action of residual enzyme and microorganisms (Galbally and Kirstine, 2002). Methanol is also produced from lignin demethylation during fungal decomposition of wood. Measured methanol emissions from plant decay range from $1.5-500 \mu \mathrm{g} / \mathrm{gDW}$ (DW=dry weight of plant), with most reported values between 130-230 $\mu \mathrm{g} / \mathrm{gDW}$ (de Gouw et al., 1999; Warneke et al., 1999; Karl et al., 2001a, b; Warneke et al., 2002). Here we apply a value of $160 \mu \mathrm{g} / \mathrm{gDW}$ from Warneke et al. (1999) to global fields of heterotrophic respiration from the CASA 2 model, following Jacob et al. (2005). Figure 2 shows the modeled distribution of the tagged tracer from this source, which totals $23 \mathrm{Tg} \mathrm{a}^{-1}$ globally.

We estimate methanol emissions from biomass burning and biofuel using gridded climatological $\mathrm{CO}$ emission inventories for these sources (Duncan et al., 2003; Yevich and
Logan, 2003). We use a methanol:CO emission ratio of $0.018 \mathrm{~mol} \mathrm{~mol}^{-1}$, consistent with a recent recommendation based on an up-to-date literature compilation (M. O. Andreae, unpublished data, 2006) and with earlier work (Jacob et al., 2005). The resulting global source of $12 \mathrm{Tg} \mathrm{a}^{-1}$ is mainly in the tropics (Fig. 2).

Anthropogenic emissions of methanol include solvent use, decomposition of biological waste, vehicle exhaust, and a number of industrial and manufacturing processes (Howard, 1990). Previous estimates of the methanol budget have concluded that these emissions account for $\sim 2 \%$ of the global source (Singh et al., 2000; Galbally and Kirstine, 2002; Heikes et al., 2002; von Kuhlmann et al., 2003a, b; Jacob et al., 2005). Winter measurements in Boulder, Colorado and Pittsburgh, Pennsylvania imply methanol:CO molar emission ratios of 0.012-0.014 (Goldan et al., 1995a; Millet et al., 2005), while ship-based measurements off the northeast coast of the United States in the summers of 2002 and 2004 indicate emission ratios of 0.004-0.011 (de Gouw et al., 2005; Warneke et al., 2007b). Ground-based measurements in Mexico City imply a slightly higher emission ratio (0.021; S. Herndon, personal communication, 2006). On the basis of this information we employ a methanol:CO emission ratio of 0.012 globally. The resulting best estimate for the global source is $4.5 \mathrm{Tg}$ annually (Fig. 2). de Gouw et al. (2005) and Warneke et al. (2007b) have suggested that the anthropogenic source of methanol is underestimated in current inventories, based on their observations of methanol correlations in the US in summer. We will test this below through comparison with the methanol-CO correlations simulated by the model.

\subsection{Methanol sinks}

The only chemical loss process known to be important for methanol is gas-phase oxidation by $\mathrm{OH}$. We use here an updated rate constant of $k=2.9 \times 10^{-12} \exp (-345 / \mathrm{T})$ from Sander et al. (2006), and apply it to archived monthly mean 3 -D fields of $\mathrm{OH}$ concentrations from a GEOS-Chem fullchemistry simulation (Millet et al., 2006a). The resulting global atmospheric lifetime of methanol due to $\mathrm{OH}$ is 13 days.

Field estimates of the methanol dry deposition velocity to land based on nighttime concentration and flux measurements range from 0.15 to $0.54 \mathrm{~cm} \mathrm{~s}^{-1}$ (Karl et al., 2004, 2005b; Talbot et al., 2005; Mao et al., 2006). Most studies of the global methanol budget have used deposition velocities in the range $0.1-0.2 \mathrm{~cm} \mathrm{~s}^{-1}$, at the low end of the measured values (Singh et al., 2000; Galbally and Kirstine, 2002; Jacob et al., 2005). An exception is Heikes et al. (2002), who used the Wesely (1989) resistance model to estimate methanol deposition velocities to land ranging from 0.04 to $0.9 \mathrm{~cm} \mathrm{~s}^{-1}$; they adopted $0.4 \mathrm{~cm} \mathrm{~s}^{-1}$ as best estimate. The measured values of $0.15-0.54 \mathrm{~cm} \mathrm{~s}^{-1}$ should in fact represent a lower limit for the methanol dry deposition velocity since they do not correct for nighttime emission from decaying vegetation and since 
dry deposition in general is faster in the day than at night (higher turbulence, higher temperature, open stomata). We find in GEOS-Chem that a deposition velocity of $0.4 \mathrm{~cm} \mathrm{~s}^{-1}$ yields a net exchange velocity (dry deposition - plant decay emission) of $0.15-0.3 \mathrm{~cm} \mathrm{~s}^{-1}$ over North America in summer, in agreement with observations, and we use that here. This results in a global average methanol lifetime against dry deposition to land of 29 days.

The main other sink of atmospheric methanol is uptake by the ocean, which is discussed below. Additional minor sinks described by Jacob et al. (2005) and implemented here in the same way are wet deposition (associated lifetime of 87 days) and in-cloud oxidation by $\mathrm{OH}(\mathrm{aq})$ (negligibly small).

\subsection{Role of the oceans}

The role of the oceans as a source or sink of methanol depends on production and loss processes within the ocean mixed layer (OML). Previous estimates of the ocean term in the atmospheric budget of methanol have assumed a constant OML saturation ratio with respect to the atmosphere (Singh et al., 2003; Jacob et al., 2005) to calculate a net air-to-sea flux. This approach makes the implicit assumption that airsea exchange controls the supply of methanol to the OML. However, if methanol in the OML is mostly produced in situ (rather than coming from the atmosphere), the resulting seato-air flux needs to be viewed as a primary source term in the atmospheric budget, separate from ocean uptake.

The first measurements of methanol concentrations in the OML were reported (Williams et al., 2004) for the tropical Atlantic (October-November 2002). Surface ocean concentrations averaged $118 \pm 48 \mathrm{nM}($ mean $\pm S D)$, with a variable net flux which in the mean was from the air to the sea $\left(66 \pm 267 \mu \mathrm{mol} \mathrm{m}^{-2} \mathrm{day}^{-1}\right)$. The measured OML concentrations are consistent with the value of $100 \mathrm{nM}$ inferred by Singh et al. (2003) on the basis of observed atmospheric concentrations and gradients over the Pacific Ocean. The OML should be a very large methanol reservoir relative to the atmosphere (Galbally and Kirstine, 2002; Singh et al., 2003): a global mean concentration of $118 \mathrm{nM}$ would imply a total mass of $66 \mathrm{Tg}$ of methanol in the OML $(0-50 \mathrm{~m})$, versus an atmospheric burden of 3-5 Tg.

The main loss processes of methanol within the oceans are likely to be microbial uptake and photochemical destruction (Heikes et al., 2002). Sinha et al. (2007) measured methanol air-sea exchange following a phytoplankton bloom in a mesocosm enclosure. The net flux was always into the ocean and was positively correlated with phytoplankton abundance, suggesting a biological role. Observed uptake rates were lower during the day, possibly reflecting competition between daytime methanol production and microbial consumption.

Based on analogous compounds, Heikes et al. (2002) estimate an OML lifetime for methanol of 3 days due to bacterial uptake. By comparison, the global sea-air exchange velocity calculated in GEOS-Chem (see below) indicates an OML ventilation timescale to the atmosphere which is much longer: over 100 days. A 3 day timescale for biotic consumption requires an OML source of $8 \times 10^{3} \mathrm{Tg} \mathrm{a}^{-1}$ to sustain the levels observed by Williams et al. (2004). We calculate using GEOS-Chem a methanol transfer rate from the atmosphere of only $100 \mathrm{Tg} \mathrm{a}^{-1}$, and conclude that a large in situ OML source must be present. This source is likely to be biological: methanol has been observed in the headspace of marine phytoplankton cultures (Daniel Riemer, personal communication), and some marine bacteria are able to transform algal carbohydrates to methanol (Heikes et al., 2002). In contrast, abiotic methanol production in the OML is thought to be minor (Heikes et al., 2002).

These considerations imply that OML methanol concentrations are controlled by in situ biological production and loss, which likely represent independent processes. The associated oceanic emission and uptake terms in the atmospheric budget should then also be viewed as independent. Previous assumptions of a constant saturation ratio with respect to the atmosphere are not physically realistic. We assume here a steady state between biotic methanol production and destruction yielding $118 \mathrm{nM}$ in the OML to match the mean in the Williams et al. (2004) data, and employ the standard two-film model described by Liss and Slater (1974):

$$
\begin{gathered}
F=K_{L}\left(\frac{c_{g}}{H}-C_{l}\right) \\
\frac{1}{K_{L}}=\frac{1}{k_{l}}+\frac{1}{H \times k_{g}} .
\end{gathered}
$$

The air-sea flux $F$ is determined by the methanol concentrations in the gas $\left(c_{g}\right)$ and liquid $\left(C_{l}\right)$ phases, the Henry's law coefficient for methanol $H$ (Snider and Dawson, 1985), and the total transfer resistance $\left(1 / K_{L}\right)$. We derive the liquid $\left(k_{l}\right)$ and gas-phase $\left(k_{g}\right)$ transfer velocities using the wind speed-dependent parameterizations of Nightingale (2000) and Asher (1997), respectively. This gives a gross flux from the ocean to the atmosphere of $85 \mathrm{Tg} \mathrm{a}^{-1}$ globally, so that the marine biosphere needs to be considered along with terrestrial plants as a major source of atmospheric methanol. This formulation also implies a large gross sink for atmospheric methanol from ocean uptake (average lifetime 11 days), comparable in magnitude to the sink from atmospheric oxidation by $\mathrm{OH}$.

Figure 3 shows the modeled net air-sea flux as an annual average. The oceans are a net sink for atmospheric methanol almost everywhere, with the strongest uptake downwind of continents where atmospheric methanol levels are high. In some regions with low atmospheric methanol concentrations and reduced solubility due to high temperatures (i.e. the tropical Pacific, the Red Sea and Persian Gulf) the model predicts a weak net ocean source. High winds over southern midlatitude oceans drive fast air-sea exchange, but this does not translate to a large modeled ocean source or sink for 


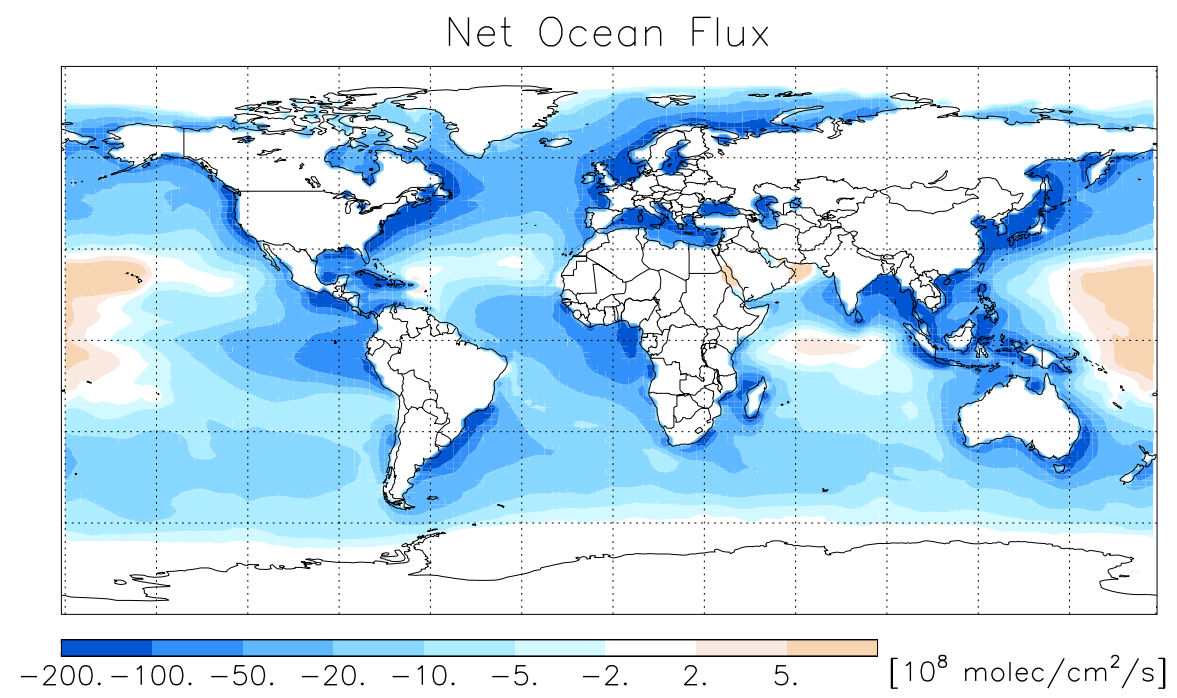

Fig. 3. Net sea-air methanol flux (annual average) for the optimized (B1Cp25) simulation. Blue colors indicate a net sink of atmospheric methanol, red colors a net source.

methanol because atmospheric concentrations are low and solubility in the cold water is high. The behavior of the ocean as a net sink for methanol is consistent with the general observation of depleted atmospheric concentrations over the oceans (Heikes et al., 2002). However, the large ocean source could cause detectable structure in atmospheric concentrations (depending on the local balance between ocean production and uptake), which we cannot describe here in the absence of better information on the OML production mechanism. Figure 2 shows the annual mean column mixing ratio of methanol from the marine biosphere. This source provides 50-200 ppt methanol over most of the globe.

Figure 4 compares simulated methanol concentrations (B1Cp25 run; 15 January-15 March) in surface air over the south Atlantic with observations from the 2007 OOMPH cruise (OOMPH, 2007). The model generally reproduces the observed concentrations over the remote ocean, in a region where marine emissions are the dominant model source of methanol (50 to $>90 \%$ ), though in fact the ocean acts as a net sink here (Fig. 3). Atmospheric production is the main other source (5 to $35 \%$, according to the model), with a small contribution from transported terrestrial emissions (generally $<10 \%$ ). There are some elevated concentrations measured over the remote Atlantic on the western cruise leg which are not captured by the model. Back-trajectories do not suggest any recent continental influence; these high observed values may result from down-mixing of free tropospheric air (ozone was also slightly elevated during this period).

\section{Model simulation of North American observations}

We compare model results with recent aircraft and ground based measurements to provide improved constraints on the methanol source terms. A major improvement over the previous model evaluation of Jacob et al. (2005) derives from the availability of extensive continental boundary layer data for North America. We use here these data to constrain the methanol source from terrestrial ecosystems and its importance relative to the marine and anthropogenic sources.

Table 1 gives details of the aircraft and surface measurements used here. Methanol measurements were made by proton-transfer reaction mass spectrometry (PTR-MS) (de Gouw et al., 2003; Karl et al., 2003, 2005b; Mao et al., 2006) or real-time gas chromatography (GC) (Millet et al., 2004, 2006b; Singh et al., 2004;), except the TOPSE measurements which were made by GC analysis of collected air canisters (D. Blake, unpublished data). The estimated accuracy for the above measurements is better than $20 \%$ in all cases $(30 \%$ for TOPSE). We also test the simulated methanol:CO correlation against aircraft observations. $\mathrm{CO}$ measurements reported here were made by vacuum UV resonance fluorescence (Holloway et al., 2000) or by differential absorption laser spectrometry (Sachse et al., 1987). Estimated accuracy is within $5 \%$ in all cases.

\subsection{Vertical profiles}

Figure 5 shows measured methanol profiles over the North American continent (black) compared to the GEOS-Chem base-case simulation (red). Because we compare model output from 2004 using climatological biomass burning to observations from multiple years, we applied a filter $\left(\mathrm{CH}_{3} \mathrm{CN}>225 \mathrm{ppt}\right.$ or $\left.\mathrm{HCN}>500 \mathrm{ppt}\right)$ to remove fire plumes. This is particularly germane for INTEX-A and ITCT-2K4 due to extensive North American boreal fires during the summer of 2004 (Pfister et al., 2005; de Gouw et al., 2006); 


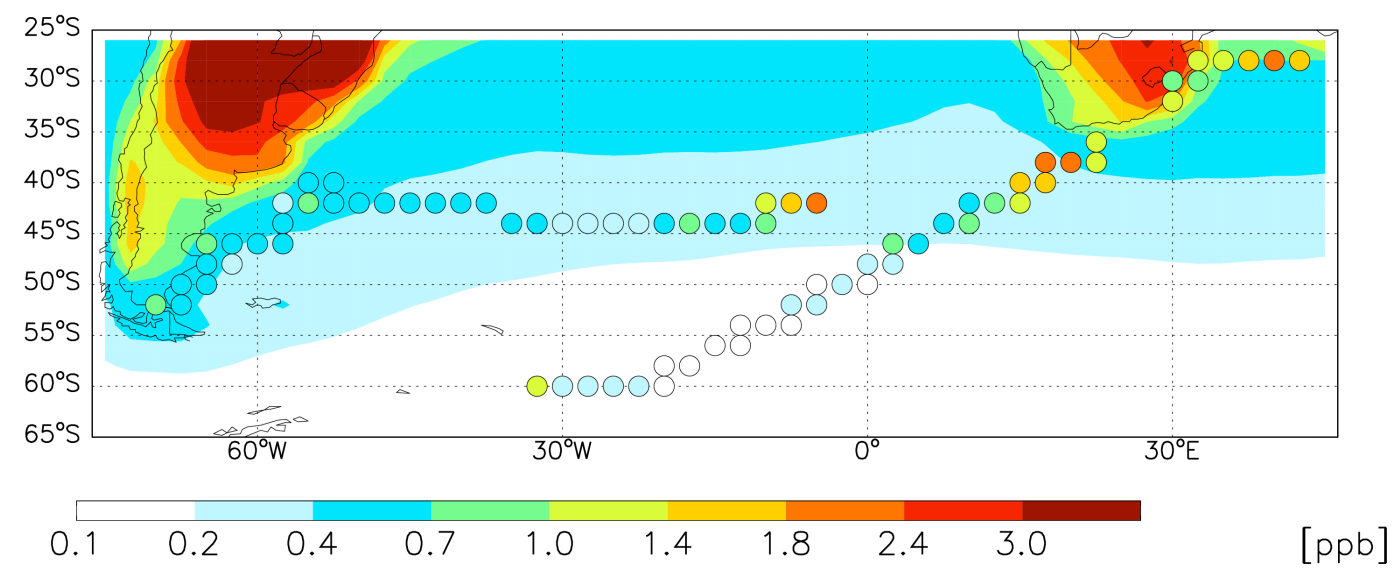

Fig. 4. Summer (15 January-15 March) methanol concentrations in surface air over the South Atlantic. Model results for the optimized B1Cp25 simulation (solid contours) are compared to ship-based observations from the 2007 OOMPH cruise (circles), with details given in Table 1.

Table 1. Aircraft and surface measurements of methanol used for model evaluation.

\begin{tabular}{|c|c|c|c|c|c|}
\hline Experiment & Timeframe & Location & Longitude & Latitude & Reference \\
\hline \multicolumn{6}{|l|}{ Aircraft Missions } \\
\hline PEM-Tropics B & Feb-Mar 1999 & Pacific & $148.7^{\circ} \mathrm{W}-84.2^{\circ} \mathrm{E}$ & $36.2^{\circ} \mathrm{S}-35.0^{\circ} \mathrm{N}$ & (Singh et al., 2001) \\
\hline TOPSE & Feb-May 2000 & Canada & $52.6^{\circ} \mathrm{W}-105.2^{\circ} \mathrm{W}$ & $39.85^{\circ} \mathrm{N}-85.1^{\circ} \mathrm{N}$ & (Atlas et al., 2003) \\
\hline ITCT-2K2 & Apr-May 2002 & US & $82.3^{\circ} \mathrm{W}-130.2^{\circ} \mathrm{W}$ & $27.7^{\circ} \mathrm{N}-48.1^{\circ} \mathrm{N}$ & (Parrish et al., 2004) \\
\hline ITCT-2K4 (ICARTT) & Jul-Aug 2004 & US & $59.3^{\circ} \mathrm{W}-85.3^{\circ} \mathrm{W}$ & $27.9^{\circ} \mathrm{N}-53.4^{\circ} \mathrm{N}$ & (Fehsenfeld et al., 2006) \\
\hline INTEX-A (ICARTT) & Jul-Aug 2004 & US, Canada & $36.2^{\circ} \mathrm{W}-139.5^{\circ} \mathrm{W}$ & $27.5^{\circ} \mathrm{N}-53.0^{\circ} \mathrm{N}$ & (Singh et al., 2006) \\
\hline MILAGRO (C130) & Mar 2006 & Mexico & $88.7^{\circ} \mathrm{W}-105.2^{\circ} \mathrm{W}$ & $16.6^{\circ} \mathrm{N}-39.9^{\circ} \mathrm{N}$ & (Karl et al., 2007a) \\
\hline MILAGRO (DC8) & Mar 2006 & US, Mexico & $86.2^{\circ} \mathrm{W}-122.0^{\circ} \mathrm{W}$ & $14.1^{\circ} \mathrm{N}-39.9^{\circ} \mathrm{N}$ & (Singh et al., 2007) \\
\hline INTEX-B (C130) & Apr-May 2006 & US & $105.0^{\circ} \mathrm{W}-141.0^{\circ} \mathrm{W}$ & $35.5^{\circ} \mathrm{N}-53.1^{\circ} \mathrm{N}$ & (Karl et al., 2007a) \\
\hline INTEX-B (DC8) & Apr-May 2006 & Pacific & $97.4^{\circ} \mathrm{W}-175.4^{\circ} \mathrm{E}$ & $19.0^{\circ} \mathrm{N}-62.1^{\circ} \mathrm{N}$ & (Singh et al., 2007) \\
\hline TEXAQS-II & Sep-Oct 2006 & US & $82.5^{\circ} \mathrm{W}-99.6^{\circ} \mathrm{W}$ & $27.5^{\circ} \mathrm{N}-34.2^{\circ} \mathrm{N}$ & (Warneke et al., 2007a) \\
\hline LBA/Claire & Mar 1998 & Surinam & $54.0^{\circ} \mathrm{W}-57.0^{\circ} \mathrm{W}$ & $2.0^{\circ} \mathrm{N}-5.0^{\circ} \mathrm{N}$ & (Williams et al., 2001) \\
\hline TROFFEE & Sep 2004 & Brazil & $58.5^{\circ} \mathrm{W}-60.3^{\circ} \mathrm{W}$ & $2.0^{\circ} \mathrm{S}-4.0^{\circ} \mathrm{S}$ & (Karl et al., 2007b) \\
\hline \multicolumn{6}{|l|}{ Surface Sites } \\
\hline Kinterbish & Jun-Jul 1990 & US & $88.8^{\circ} \mathrm{W}$ & $32.3^{\circ} \mathrm{N}$ & (Goldan et al., 1995b) \\
\hline Tennessee & Jun 1995 & US & $86.5^{\circ} \mathrm{W}$ & $36.1^{\circ} \mathrm{N}$ & (Riemer et al., 1998) \\
\hline Univ. of Michigan & Sep-Oct 2001 & US & $84.7^{\circ} \mathrm{W}$ & $45.6^{\circ} \mathrm{N}$ & (Karl et al., 2003) \\
\hline Biological Station & $\begin{array}{r}\text { May-Jun } 2002 \\
\text { Jul-Aug } 2005\end{array}$ & & & & \\
\hline Trinidad Head & Apr-May 2002 & US & $124.2^{\circ} \mathrm{W}$ & $41.1^{\circ} \mathrm{N}$ & (Millet et al., 2004) \\
\hline Duke Forest & Jul 2003 & US & $79.1^{\circ} \mathrm{W}$ & $36.0^{\circ} \mathrm{N}$ & (Karl et al., 2005b) \\
\hline Chebogue Point & Jul-Aug 2004 & Canada & $66.1^{\circ} \mathrm{W}$ & $43.8^{\circ} \mathrm{N}$ & (Millet et al., 2006b) \\
\hline Appledore Island & Jul-Aug 2004 & US & $70.6^{\circ} \mathrm{W}$ & $43.0^{\circ} \mathrm{N}$ & (Mao et al., 2006) \\
\hline Thompson Farm & Jul-Aug 2004 & US & $71.0^{\circ} \mathrm{W}$ & $43.1^{\circ} \mathrm{N}$ & (Mao et al., 2006) \\
\hline Rondônia & Oct 1999 & Brazil & $62.9^{\circ} \mathrm{W}$ & $10.1^{\circ} \mathrm{S}$ & (Kesselmeier et al., 2002) \\
\hline Amazonas & Sep 2004 & Brazil & $60.2^{\circ} \mathrm{W}$ & $2.6^{\circ} \mathrm{S}$ & (Karl et al., 2007b) \\
\hline \multicolumn{6}{|l|}{ Ship Cruises } \\
\hline NEAQS-2K2 & Jul-Aug 2002 & North Atlantic & $66.2^{\circ} \mathrm{W}-71.1^{\circ} \mathrm{W}$ & $41.7^{\circ} \mathrm{N}-44.5^{\circ} \mathrm{N}$ & (Warneke et al., 2004) \\
\hline OOMPH & Jan-Mar 2007 & South Atlantic & $69.6^{\circ} \mathrm{W}-42.0^{\circ} \mathrm{E}$ & $27.1^{\circ} \mathrm{S}-59.9^{\circ} \mathrm{S}$ & (OOMPH, 2007) \\
\hline
\end{tabular}




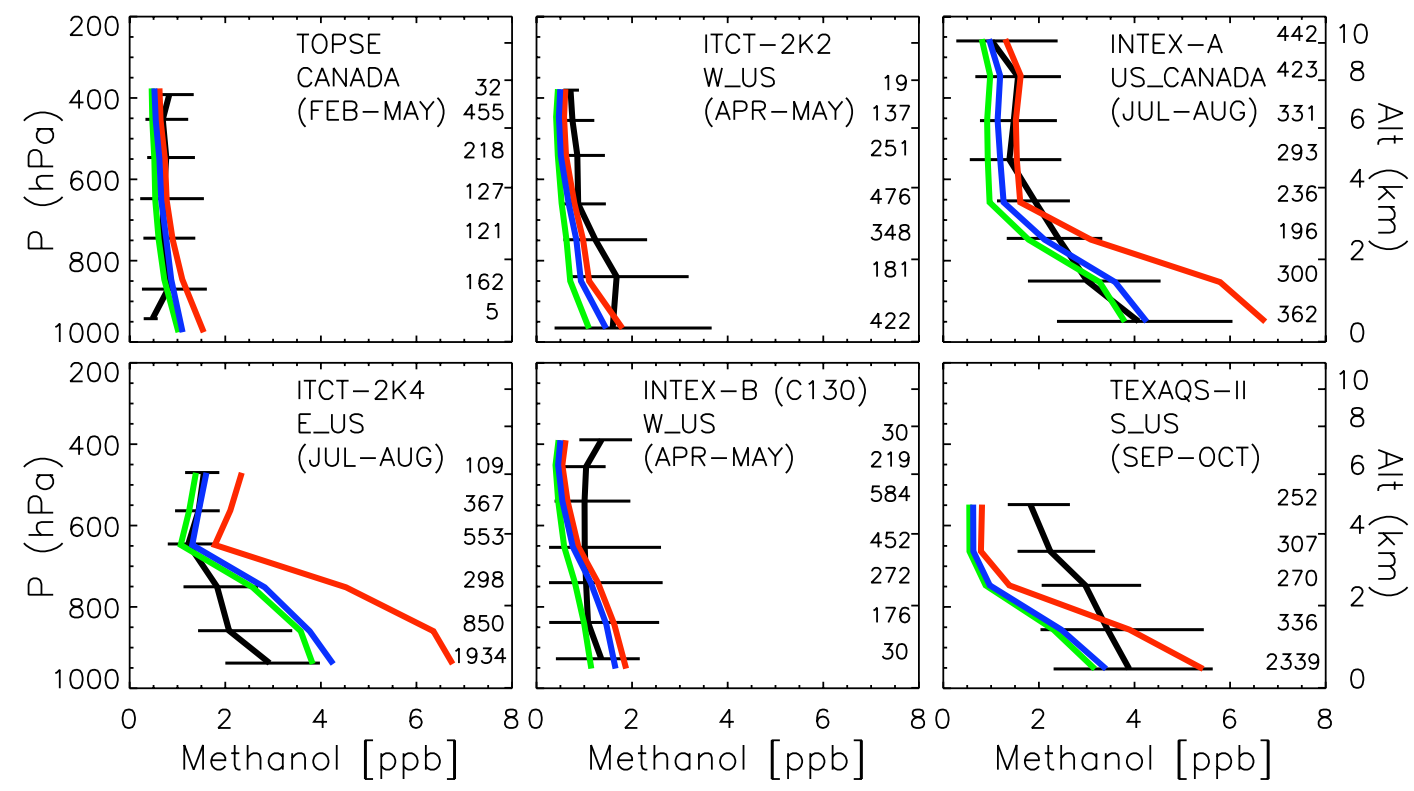

Fig. 5. Vertical profiles of methanol concentrations over North America. Aircraft measurements are shown in black with the standard deviation for each altitude bin indicated by the horizontal lines. Colored lines show the GEOS-Chem profiles for the base-case simulation (red) and two sensitivity runs with the biogenic source reduced. Green lines (Biog50 scenario): emissions from all plant functional types (PFTs) reduced by a factor of two. Blue lines (B1Cp25 scenario): emissions from broadleaf trees and crops reduced by a factor of four, other PFTs left at their base rate. The INTEX-B data have been filtered of three polluted boundary layer legs to better reflect broad-scale inflow. Here and elsewhere, the model is sampled along the flight tracks at the same hour and day of year as the measurements. See Table 1 for details.

4-10\% of the observations were excluded in this case. The base-case simulation exhibits a large boundary layer overestimate over the eastern and southern US in summer (INTEXA, ITCT-2K4, TEXAQS-II). Below we show that this reflects an overestimate of biogenic emissions. Measurements over the western US (ITCT-2K2 and INTEX-B) reflect the inflow boundary conditions for North America and are well captured by the model. The model is generally unbiased in the free troposphere, except for a significant low bias over Texas (TEXAQS-II) which may reflect insufficient model convection in the region (the simulated $\mathrm{CO}$ profile is also steeper than observed).

Figure 6 compares measured and simulated methanol profiles over the ocean, after filtering out polluted air $(\mathrm{CO}>150 \mathrm{ppb})$. Our new air-sea flux parameterization yields a vertical profile shape which is generally consistent with observations. An exception is the eastern Pacific data (ITCT2K2 and C130-INTEX-B), where the model significantly underpredicts the free tropospheric concentrations and the strength of the vertical gradient. The measured vertical gradients in these datasets suggest enhanced methanol uptake near the coast, not reflected in the model, perhaps due to high biological productivity or upwelling of cold methanol-depleted deep water. Agreement is better with the PEM-TB and DC8-INTEX-B observations from the more remote Pacific. The latter measurements were made by in situ GC (time resolution $5 \mathrm{~min}$ ), whereas the ITCT-2K2 and C130-INTEX-B measurements were made by PTR-MS (time resolution $<1 \mathrm{~min}$ ).

\subsection{North American boundary layer}

Figure 7 shows boundary layer methanol concentrations over North America observed from aircraft in spring-summer. Also shown are model results sampled along the flight tracks. The high model bias over eastern North America, seen earlier in the vertical profiles, is again manifest. We infer that the terrestrial biogenic source is too high, as this source is the main contributor to methanol concentrations over North America during summer. An alternate explanation would be model underestimate of the methanol sinks (dry deposition, oxidation by $\mathrm{OH}$, boundary layer ventilation) but that does not seem viable. Dry deposition loss is constrained by surface measurements as described above. Average modeled $\mathrm{OH}$ concentrations in the continental boundary layer are consistent with INTEX-A aircraft observations (Hudman et al., 2007) after accounting for a $+64 \%$ measurement correction (Ren et al., 2008). Hudman et al. (2008) and Xiao et al. (2007) found no apparent bias in GEOS-Chem boundary layer ventilation from simulation of the vertical profiles of hydrocarbons (propane, acetylene) observed by the INTEXA aircraft. 


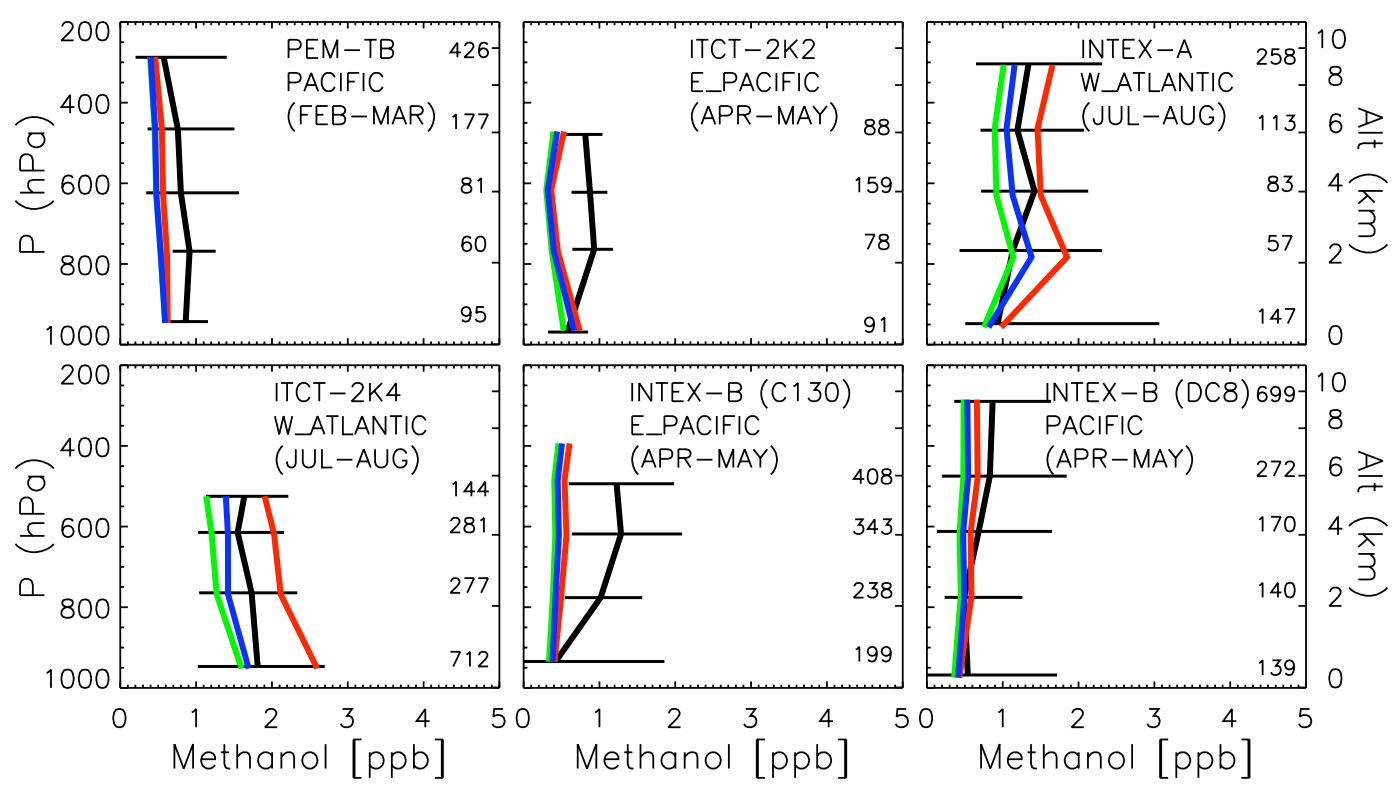

Fig. 6. Vertical profiles of methanol concentrations over ocean (note different $\mathrm{x}$-axis scale compared to Fig. 5). Polluted air $(\mathrm{CO}>150 \mathrm{ppb})$ has been removed to better isolate the effect of air-sea exchange. Colors as in Fig. 5. See Table 1 for details.

The spatial distribution of the bias in Fig. 7, when compared to the PFT distribution in Fig. 1, suggests that the source overestimate is mostly from broadleaf trees and possibly crops. In the West, where grasslands and evergreens dominate, the model shows instead a weak negative bias. The eastern North America data in Fig. 7 are for July-August. To determine whether the bias reflects error in the PFT-specific base emission rates (i.e. $\varepsilon_{i}$ in Eq. 1) or in the seasonal variation $(\gamma)$, we compare in Fig. 8 model results to June-October observations at the University of Michigan Biological Station (UMBS), a mixed hardwood forest in northern Michigan $\left(45.56^{\circ} \mathrm{N}, 84.71^{\circ} \mathrm{W}\right)$ (Karl et al., 2003), which is to our knowledge the only seasonal record available for a broadleaf tree PFT environment. The seasonal cycle, normalized to the June mean, from the base-case simulation (shown in red) agrees well with the observations (the normalization factor is 7.0 in both cases). Schade and Goldstein (2006) have published the first full-year cycle of atmospheric methanol, measured at Blodgett Forest, a Ponderosa pine forest in eastern California $\left(38.90^{\circ} \mathrm{N}, 120.63^{\circ} \mathrm{W}\right)$. The measured and simulated concentrations at this site (not shown) both peak in spring-summer and exhibit a fall-winter minimum, reflecting the seasonality of the biogenic source (plant decay emissions and photochemical production are also lower in winter). Neither the UMBS nor the Blodgett datasets provide any indication of a seasonal bias in the modeled biogenic source that could explain the observed discrepancy.

Summer 2004 in the US Northeast was uncharacteristically cool and damp (Thompson et al., 2007), but this is not the cause of the model:measurement bias. First, the JulyAugust mean methanol concentration measured at Thomp- son Farm, NH during 2004 was only $4-14 \%$ lower than in 2005-2007, which is much less than the discrepancy observed here. Second, Millet et al. (2006a) found HCHO concentrations measured over North America during INTEX-A (largely from isoprene oxidation) during summer 2004 to be well-simulated by GEOS-Chem, suggesting that the model is able to capture the regional climatology and associated biological effects. We therefore attribute the model error to the base emission rates.

Major axis regression of simulated vs. observed methanol concentrations for the boundary layer data in INTEX-A and ITCT-2K4 gives a slope of 1.6 (INTEX-A) and 2.6 (ITCT$2 \mathrm{~K} 4$ ), with a median model bias of $+75 \%$ and $+111 \%$ respectively. We find that we can remove most of the bias in the base-case simulation by either reducing biogenic emissions from all PFTs by a factor of 2, or reducing emissions from broadleaf trees and crops by a factor of 4 (with emissions from other PFTs left at the base-case rate). This results in a global methanol source from living foliage of $72 \mathrm{Tg}$ in the first case and $89 \mathrm{Tg}$ in the second (vs. $145 \mathrm{Tg}$ in the basecase simulation). Both of these optimized simulations are of comparable quality in terms of reproducing the observations, with the model bias reduced to within $30 \%$ in both cases. The regression slopes indicate some residual overestimate for ITCT-2K4 (slop=1.4-1.6), but not over the more extensive INTEX-A domain (slope $=0.9-1.0$ ). Figures 5-7 show that both of the optimized simulations better capture methanol concentration patterns over North America and the adjacent oceans. 

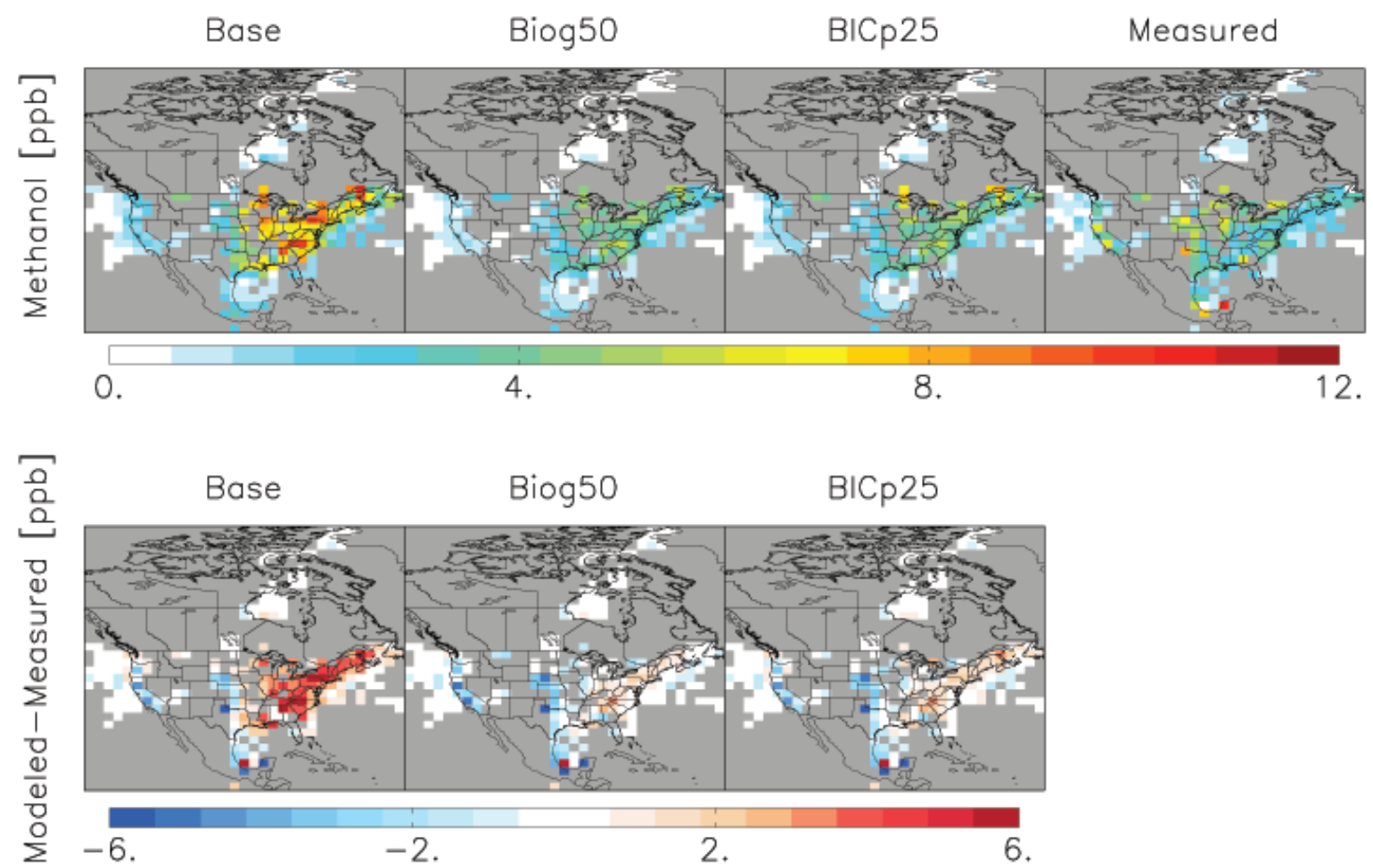

Fig. 7. Top panels: boundary layer $(P>800 \mathrm{hPa})$ methanol concentrations measured for the ensemble of aircraft campaigns in Table 1 , and corresponding values simulated with the GEOS-Chem model for the base case and two sensitivity cases with the terrestrial biogenic source reduced. Bottom panels: differences between model and measured values. The eastern North America data (INTEX-A, ITCT-2K4) are for July-August, and the western data (ITCT-2K2, INTEX-B) are for April-May. Data over the Gulf Coast and Mexico are for March (MILAGRO) and September-October (TEXAQS-II). The observations are mapped on the $2^{\circ} \times 2.5^{\circ}$ model grid and the model results are sampled along the aircraft flight tracks at the same hour and day of year as the measurements.

The reduced emissions from terrestrial vegetation inferred from the aircraft data are also generally consistent with North American surface measurements. Figure 9 shows simulated methanol concentrations in surface air compared to rural ground station observations and ship-based measurements off the US east coast (information is given in Table 1). Even with the reduced biogenic source, the model overestimates at some sites (Duke Forest, Thompson Farm, Chebogue Point). On the other hand the model is biased low relative to observations at the University of Michigan Biological Station, as well as earlier measurements from the rural US Southeast (Kinterbish and Tennessee). The latter were the only summertime datasets over land available to Jacob et al. (2005) in their earlier evaluation of the global methanol budget. There appears to be significant variability in methanol emission rates between ecosystems which is not constrained by current understanding. However, overall the optimized runs provide an improved simulation relative to North American surface measurements. We will show in Sect. 4 that the same is true in the tropics.

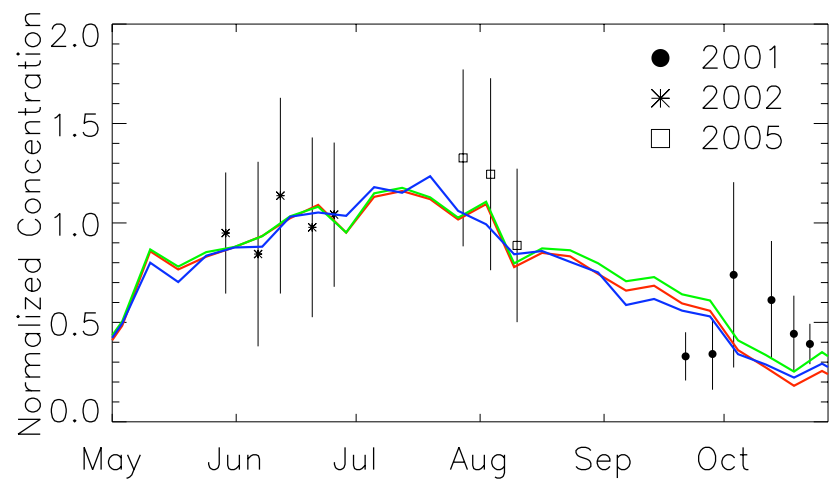

Fig. 8. Seasonal cycle of methanol concentrations (normalized to the June mean) as observed at the University of Michigan Biological Station (Karl et al., 2003), compared to the base-case (red), Biog50 (green) and B1Cp25 (blue) simulations.

Some discrepancies persist with the optimized simulations. The first is the residual high bias seen over eastern North America relative to both the surface and ITCT2K4 aircraft data (Figs. 5, 7, 9). Further reduction of the 


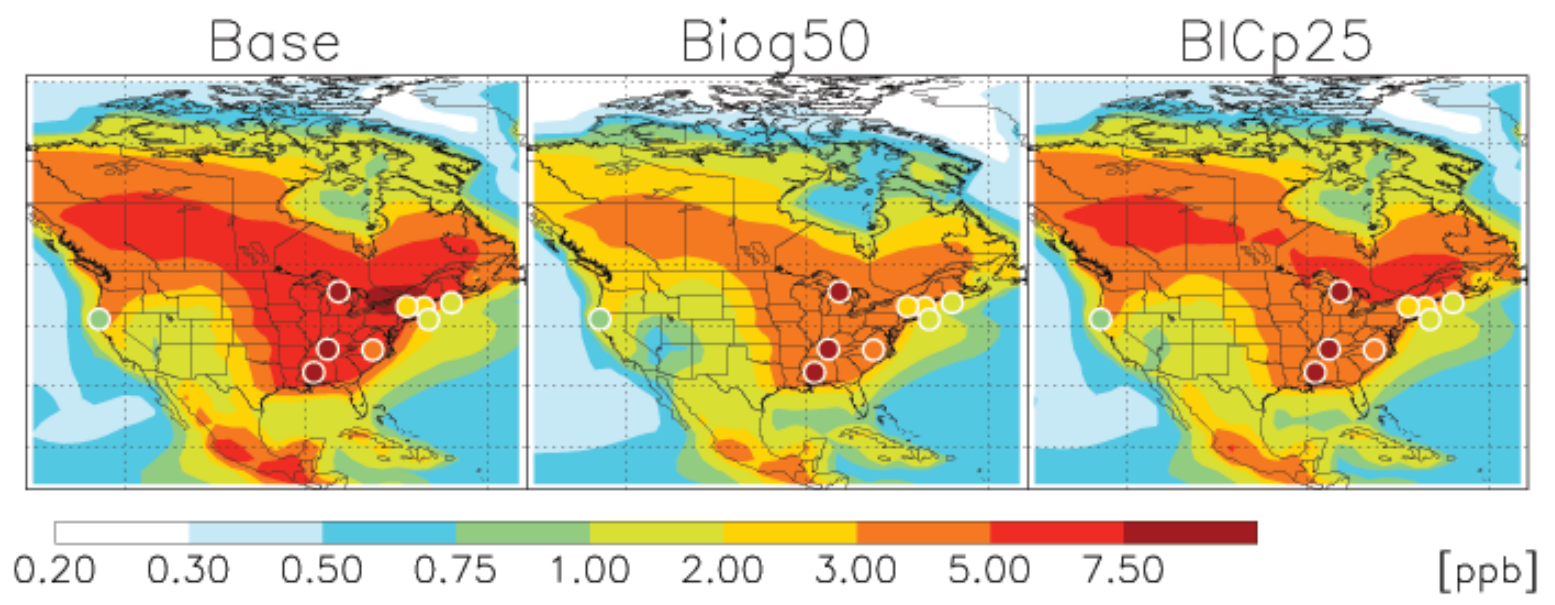

Fig. 9. Summer (1 July-15 August) 24-h average methanol concentrations in North American surface air. Model results are compared to rural ground station and ship-based observations (circles), with details given in Table 1 (Trinidad Head, CA observations are for April-May). The datapoints for Thompson Farm, New Hampshire and NEAQS-2K2 have been shifted west by $2.5^{\circ}$ and south by $2^{\circ}$, respectively, to distinguish them from that of nearby Appledore Island.

terrestrial biogenic source does not seem warranted, as other surface measurements do not imply a high bias, nor do the INTEX-A aircraft data. The disparity points to particularly low methanol emissions from plant species prevalent in the northeastern US and southeastern Canada. There is also a weak low bias over the western US (Fig. 7), suggesting some underestimate of emissions from western ecosystems. The bias is not corrected by reasonable upward adjustment of grassland emissions owing to low associated NPP. Finally, the variability between surface sites is not captured by the model. Overall, these findings imply that the relationship of methanol emission to NPP is more variable than proposed by Galbally and Kirstine (2002), who estimated a range of 0.08$0.14 \%$ for higher plants. It is possible that plant metabolism and bacterial consumption of methanol on leaf surfaces degrade the relationship between NPP and net methanol emissions to the atmosphere (Fall and Benson, 1996).

\subsection{Importance of anthropogenic vs. biogenic sources}

We searched for correlations in the ICARTT data between methanol concentrations and the large ensemble of other chemical variables measured aboard the aircraft. One of the strongest correlations for the combined dataset is with $\mathrm{CO}\left(R^{2}=0.51-0.61\right.$ for all data; $R^{2}=0.41-0.46$ in the boundary layer after removing biomass burning plumes). Both compounds have a similar array of terrestrial sources (biogenic + urban/industrial), though in different proportions: CO sources over the US during ICARTT included comparable contributions from combustion and from photochemical oxidation of biogenic VOCs, and the corresponding GEOSChem simulation is unbiased relative to the ICARTT observations (Hudman et al., 2008). Also contributing to the correlation is the fact that methanol is sufficiently long-lived that it will persist as $\mathrm{CO}$ is photochemically produced from more reactive precursor VOCs such as isoprene. On the other hand, we find that methanol and $\mathrm{CO}$ are in general not as wellcorrelated in the non-urban surface datasets or over the ocean (and this is also captured by the model).

Figure 10 shows simulated and observed methanol:CO correlations for the ICARTT and TEXAQS-II aircraft experiments. The model reproduces the correlations seen in the observations. Methanol:CO slopes for the optimized runs agree more closely with observations than the base-case scenario, and are within $25 \%$ of measured values (with the exception of a remaining high bias over the ITCT-2K4 domain). The lowest correlation is seen over the US Northeast (ITCT-2K4), where the biogenic contribution to $\mathrm{CO}$ is smaller than elsewhere in the eastern US (Griffin et al., 2007).

While INTEX-A was a broad-scale study extending across North America, ITCT-2K4 and TEXAQS-II focused more on sampling urban plumes. Figure 10 shows that urban plumes were encountered during ITCT-2K4 with $\mathrm{CO}$ values above $300 \mathrm{ppb}$ and these also had elevated methanol concentrations. While individual plumes are not captured at the $2^{\circ} \times 2.5^{\circ}$ resolution of GEOS-Chem, the associated methanol:CO enhancement ratio $(0.010-0.015)$ is consistent with what we expect based on the modeled anthropogenic methanol source. Anthropogenic methanol emissions thus have a discernable impact on the ITCT-2K4 dataset, but only minor implications for the regional budget.

Our successful simulation of the observed methanol:CO correlations and slopes given independent constraints on CO sources (Hudman et al., 2008) provides further support for our updated biogenic source estimates without having to invoke a significant anthropogenic source for methanol. In contrast, Schade and Goldstein (2001) and de Gouw et 


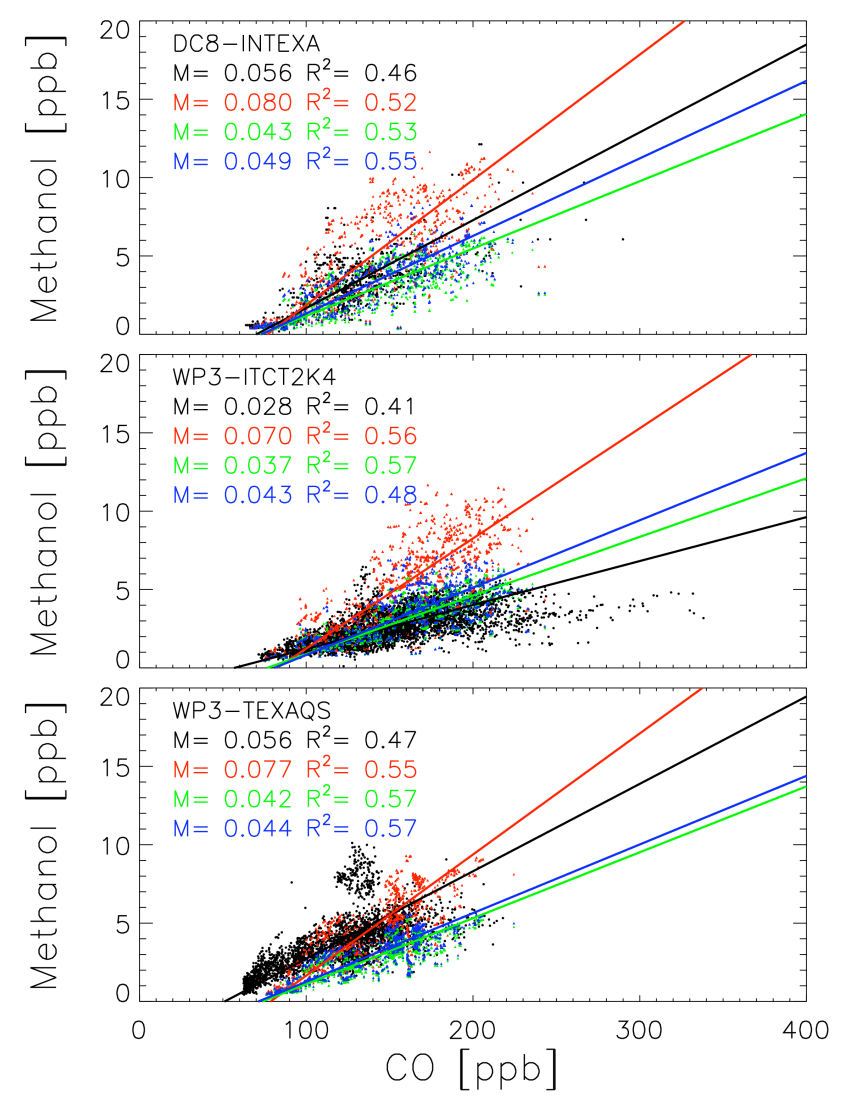

Fig. 10. Boundary-layer $(P>800 \mathrm{hPa})$ methanol:CO correlations from the INTEX-A, ITCT-2K4, and TEXAQS-II aircraft campaigns over North America (Table 1). Measurements (in black) are compared to simulated concentrations with colors as in Fig. 5.

al. (2005) applied correlations of surface methanol concentrations with other chemical variables to estimate summer anthropogenic:biogenic ratios for above-background methanol concentrations of 0.6 (eastern California) and 1.65 (downwind of the US Northeast). We believe that this inference of a large anthropogenic source of methanol is incorrect and results from a lack of suitable tracers for unambiguous source separation. In Schade and Goldstein (2001), 2-methyl-3buten-2-ol (locally emitted) and methyl-t-butyl-ether (emitted upwind) were used as biogenic and anthropogenic tracers, conflating anthropogenic with upwind biogenic sources. In de Gouw et al. (2005), isoprene (plus its first-generation oxidation products methacrolein and methyl vinyl ketone) was used as the biogenic tracer, a poorly-conserved indicator which will underestimate biogenic sources in aged air. Even when suitable tracers exist, separating sources based on correlations can be difficult because of co-located sources (e.g. anthropogenic vs. urban/suburban vegetation sources) and transport effects.

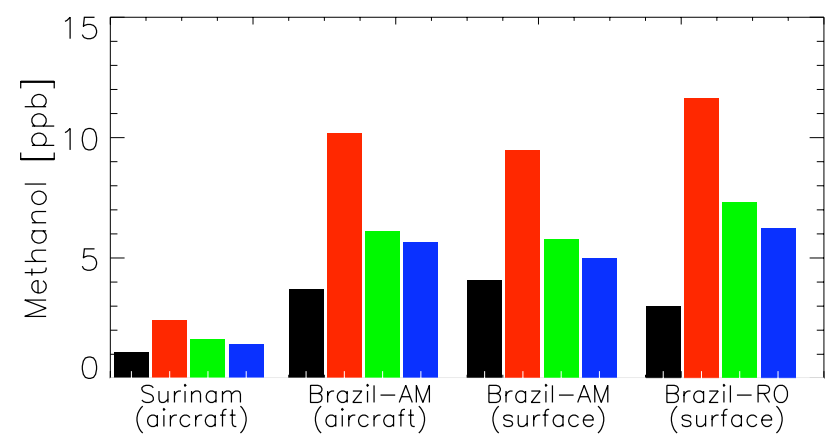

Fig. 11. Tropical boundary layer methanol concentrations $(P>800 \mathrm{hPa}$ in the case of the aircraft data). Average measured concentrations (black) are compared to simulated concentrations over Surinam during the wet season and the Brazilian states of Amazonas (AM) and Rondônia (RO) during the dry season. Colors are as in Fig. 5. See Table 1 for details.

\section{Updated global budget}

Our reduction of the terrestrial biogenic source improves the methanol simulation not only over North America but over the tropics as well. Only a few tropical measurements are available, all in South America (Table 1), and these are compared to model results in Fig. 11. Aircraft and surface measurements over the Amazon, averaging 34 ppb in September-October (dry season) (Kesselmeier et al., 2002; Karl et al., 2007b) and $1.1 \mathrm{ppb}$ in March (wet season) (Williams et al., 2001), are overpredicted by a factor of 2-4 with the base-case simulation. The high bias is reduced substantially with the optimized sources; simulated concentrations are then 5-7 ppb (dry season) and 1.4-1.6 ppb (wet season). This provides some confidence that our findings of a reduced source from the North American terrestrial biosphere can be extrapolated to give a more accurate global methanol budget. While the optimized runs are still too high relative to the limited tropical measurements, the overall agreement with more extensive observations over North America, the remote Pacific and in the free troposphere argues against further reduction of the terrestrial biogenic source.

The source optimization does not significantly degrade the simulation of other aircraft and surface datasets presented in Jacob et al. (2005). The level of agreement with measurements over Europe is improved or unchanged in the free troposphere (Zugspitze, MINOS campaign) and slightly degraded in the boundary layer (MINOS, Innsbruck) (Holzinger et al., 2001; Lelieveld et al., 2002; A. Hansel and A. Wisthaler, unpublished data, 2003). Model agreement with aircraft data over the North Pacific (TRACE-P) and North Atlantic (SONEX) is not appreciably changed (Singh et al., 2000, 2003, 2004). Simulation of observations in the Arctic boundary layer (AOE cruise) is improved south of $84^{\circ} \mathrm{N}$ but degraded farther north (A. Hansel and A. Wisthaler, unpublished data, 2001). 
Table 2. Global atmospheric methanol budget.

\begin{tabular}{lrr}
\hline Sources $\left(\mathrm{Tg} \mathrm{a}^{-1}\right)$ & This Work & Previous Estimates $^{\mathrm{a}}$ \\
\hline Ocean biosphere & 85 & Note $^{\mathrm{b}}$ \\
Terrestrial plant growth & 80 & $75-312$ \\
Atmospheric production & 37 & $18-38$ \\
Plant decay & 23 & $13-23$ \\
Biomass + biofuel burning & 12 & $6-15$ \\
Urban & 5 & $2-8$ \\
Total Sources & 242 & $122-350$ \\
\hline Sinks (Tg a & \\
\hline Ocean uptake & & \\
Gas-phase oxidation by OH & 101 & Note \\
Dry deposition to land & 88 & $59-149$ \\
Wet deposition & 40 & $24-70$ \\
In-cloud oxidation by OH(aq) & 13 & $9-50$ \\
Total Sinks & $<1$ & $0-10$ \\
& 242 & $40-284$ \\
Atmospheric Inventory (Tg) & 3.1 & $1.9-4.7$ \\
Atmospheric Lifetime (days) & 4.7 & $5-12$ \\
\hline
\end{tabular}

a Singh et al., 2000; Galbally and Kirstine, 2002; Heikes et al., 2002; Tie et al., 2003; von Kuhlmann et al., 2003 a, b; Jacob et al., 2005.

$\mathrm{b}$ Previous studies have estimated a range of $0-50 \mathrm{Tg} \mathrm{a}^{-1}$ for net ocean uptake.

Table 2 shows our updated global budget. Emissions from marine $\left(85 \mathrm{Tg} \mathrm{a}^{-1}\right)$ and terrestrial $\left(80 \mathrm{Tg} \mathrm{a}^{-1}\right)$ biota are of comparable magnitude. The spatial distribution of methanol over North America points to a reduced source (factor of 4) from broadleaf trees and crops, but a uniform (factor of two) reduction of emissions from all PFTs also agrees well with observations. Our recommended plant growth source reflects the average of these two optimized source estimates (72 and $89 \mathrm{Tg} \mathrm{a}^{-1}$ ).

Together with a smaller contribution from plant decay $\left(23 \mathrm{Tg} \mathrm{a}^{-1}\right)$, biogenic emissions from the land and ocean account for $\sim 80 \%$ of the total source. Ocean uptake is the main sink $\left(101 \mathrm{Tg} \mathrm{a}^{-1}\right)$ along with oxidation by $\mathrm{OH}\left(88 \mathrm{Tg} \mathrm{a}^{-1}\right)$. Our revised estimate for dry deposition loss is $40 \mathrm{Tg} \mathrm{a}^{-1}$. With a minor wet deposition sink $\left(13 \mathrm{Tg} \mathrm{a}^{-1}\right)$, we derive an annual global atmospheric burden of $3.1 \mathrm{Tg}$, which is within the range $(1.9-4.7 \mathrm{Tg})$ estimated by Tie et al. (2003) but lower than other assessments of the methanol budget (3.44.0 Tg) (Galbally and Kirstine, 2002; Heikes et al., 2002; Jacob et al., 2005). Our calculated atmospheric lifetime is 4.7 days, shorter than the other studies compiled by Jacob et al. (2005) (5-12 days), because we account for uptake by the ocean as a gross process whereas previous studies accounted for it as a net process (partly compensated by oceanic emission).

Urban emissions, constrained by measured methanol:CO enhancements in polluted air, are a minor term in the global budget (though they can be regionally significant in winter): our best estimate is $5 \mathrm{Tg} \mathrm{a}^{-1}$ globally. Over North America, our best estimate of the anthropogenic methanol source is $0.5 \mathrm{Tg} \mathrm{a}^{-1}$, compared to $11 \mathrm{Tg} \mathrm{a}^{-1}$ from plant growth and $3 \mathrm{Tg} \mathrm{a}^{-1}$ from plant decay.

\section{Conclusions}

We used an ensemble of recent aircraft and surface measurements of methanol concentrations together with a global 3-D chemical transport model (GEOS-Chem) to test our understanding of global methanol sources and sinks. Measurements of methanol concentrations in the ocean mixed layer (OML) (Williams et al., 2004), together with an estimated 3 -day lifetime in the OML against bacterial uptake (Heikes et al., 2002) imply the presence of a large in situ biological source, as transfer from the atmosphere cannot balance the loss. Previous model studies have only described the net loss of atmospheric methanol to the ocean, but ocean emission and ocean uptake should in fact be viewed as separate terms in the atmospheric methanol budget. Absent marine production, the oceans would be a much larger net global sink for atmospheric methanol. We estimate a large global ocean source to the atmosphere on the basis of the OML concentrations reported by Williams et al. (2004), so that marine and terrestrial biota are of comparable global importance as sources of atmospheric methanol. This separation of ocean source and sink terms in the atmospheric methanol budget also means that ocean uptake is a major global sink of atmospheric methanol, comparable in magnitude to oxidation by $\mathrm{OH}$. Our analysis is based on the only published dataset of methanol concentrations in the surface ocean (Williams et al., 2004), though these measurements do agree with inferred levels elsewhere (Singh et al., 2003). More process-level information on methanol in the OML is needed to build on the initial work presented here.

We find that previous estimates of the dominant plant growth source are too high relative to methanol observations over North America and in the tropics. The bias in North America correlates with regions of high broadleaf tree and crop coverage, suggesting a factor of four overestimate of emissions from these plant functional types (PFTs). However, a uniform factor of two emission decrease across all PFTs also yields a similar improvement. Our best estimate of the global source from live foliage is $80 \mathrm{Tg} \mathrm{a}^{-1}$ based on the average of these two scenarios. While the optimized simulations give a more accurate picture of the mean methanol distribution at regional and larger scales, they do not capture the high observed site-to-site variability in methanol concentrations, and in both cases there remains a weak high bias over the US Northeast and a weak low bias over the western US. We conclude that the relationship of methanol emission to NPP is weaker and more variable than previously thought. More extensive measurements defining how 
methanol emissions depend on PFT and season would help to resolve these issues and further refine the overall budget.

Methanol is strongly correlated with $\mathrm{CO}$ in summertime observations over North America during summer $\left(R^{2}=0.51-\right.$ 0.61 for the entire ICARTT dataset; $R^{2}=0.41-0.46$ in the boundary layer) despite the absence of a large anthropogenic methanol source. The model reproduces the correlations and slopes observed over North America given independent constraints on CO emissions (Hudman et al., 2008), which provides support for our reduced terrestrial biogenic source.

Our best estimate for the global methanol source is $242 \mathrm{Tg} \mathrm{a}^{-1}$, with $85 \mathrm{Tg} \mathrm{a}^{-1}$ from the marine biosphere, $103 \mathrm{Tg} \mathrm{a}^{-1}$ from terrestrial plant growth and decay, $37 \mathrm{Tg} \mathrm{a}^{-1}$ from atmospheric production, $12 \mathrm{Tg} \mathrm{a}^{-1}$ from the burning of biomass and biofuels, and $5 \mathrm{Tg} \mathrm{a}^{-1}$ from urban and industrial sources. We deduce an atmospheric lifetime from methanol of 5 days, a factor of 2 shorter than previous studies, reflecting the separation of the oceanic emission and uptake terms in the atmospheric budget. We find that ocean uptake contributes $42 \%$ of the global sink, gas-phase oxidation by $\mathrm{OH} 36 \%$, dry deposition to land $17 \%$, and wet deposition $5 \%$.

Acknowledgements. This work was supported by the Atmospheric Chemistry Program of the US National Science Foundation. We thank John Holloway, Glen Sachse, and Glenn Diskin for providing CO data, and Donald Blake for providing unpublished methanol data from TOPSE. DBM thanks the NOAA Climate and Global Change Postdoctoral Fellowship Program and Harvard University's Reginald A. Daly Postdoctoral Fellowship Program, Brendan Field for his assistance, and Bob Yantosca for his generous help.

Edited by: J. Rinne

\section{References}

Asher, W.: The sea-surface microlayer and its effect on global airsea gas transfer, in: The Sea Surface and Global Change, edited by: Peter, S. L. and Robert, A. D., Cambridge University Press, Cambridge, UK, 1997.

Atlas, E. L., Ridley, B. A., and Cantrell, C. A.: The Tropospheric Ozone Production about the Spring Equinox (TOPSE) experiment: Introduction, J. Geophys. Res., 108, 8353, doi:10.1029/2002JD003172, 2003.

Bertschi, I., Yokelson, R. J., Ward, D. E., Babbitt, R. E., Susott, R. A., Goode, J. G., and Hao, W. M.: Trace gas and particle emissions from fires in large diameter and belowground biomass fuels, J. Geophys. Res., 108, 8472, doi:10.1029/2002JD002100, 2003.

Bey, I., Jacob, D. J., Yantosca, R. M., Logan, J. A., Field, B. D., Fiore, A. M., Li, Q. B., Liu, H. G. Y., Mickley, L. J., and Schultz, M. G.: Global modeling of tropospheric chemistry with assimilated meteorology: Model description and evaluation, J. Geophys. Res., 106, 23 073-23 095, 2001.

Carpenter, L. J., Lewis, A. C., Hopkins, J. R., Read, K. A., Longley, I. D., and Gallagher, M. W.: Uptake of methanol to the North
Atlantic Ocean surface, Global Biogeochem. Cy., 18, GB4027, doi:10.1029/2004GB002294, 2004.

Christian, T. J., Kleiss, B., Yokelson, R. J., Holzinger, R., Crutzen, P. J., Hao, W. M., Saharjo, B. H., and Ward, D. E.: Comprehensive laboratory measurements of biomass-burning emissions: 1. Emissions from Indonesian, African, and other fuels, J. Geophys. Res., 108, 4719, doi:10.1029/2003JD003704, 2003.

de Gouw, J., Warneke, C., Karl, T., Eerdekens, G., van der Veen, C., and Fall, R.: Sensitivity and specificity of atmospheric trace gas detection by proton-transfer-reaction mass spectrometry, Int. J. Mass Spectrom., 223, 365-382, 2003.

de Gouw, J. A., Howard, C. J., Custer, T. G., and Fall, R.: Emissions of volatile organic compounds from cut grass and clover are enhanced during the drying process, Geophys. Res. Lett., 26, 811-814, 1999.

de Gouw, J. A., Middlebrook, A. M., Warneke, C., Goldan, P. D., Kuster, W. C., Roberts, J. M., Fehsenfeld, F. C., Worsnop, D. R., Canagaratna, M. R., Pszenny, A. A. P., Keene, W. C., Marchewka, M., Bertman, S. B., and Bates, T. S.: Budget of organic carbon in a polluted atmosphere: Results from the New England Air Quality Study in 2002, J. Geophys. Res., 110, D16305, doi:10.1029/2004JD005623, 2005.

de Gouw, J. A., Warneke, C., Stohl, A., Wollny, A. G., Brock, C. A., Cooper, O. R., Holloway, J. S., Trainer, M., Fehsenfeld, F. C., Atlas, E. L., Donnelly, S. G., Stroud, V., and Lueb, A.: Volatile organic compounds composition of merged and aged forest fire plumes from Alaska and western Canada, J. Geophys. Res., 111, D10303, doi:10.1029/2005JD006175, 2006.

DeFries, R. S., Hansen, M. C., Townshend, J. R. G., Janetos, A. C., and Loveland, T. R.: A new global 1-km dataset of percentage tree cover derived from remote sensing, Glob. Change Biol., 6, 247-254, 2000.

Duncan, B. N., Martin, R. V., Staudt, A. C., Yevich, R., and Logan, J. A.: Interannual and seasonal variability of biomass burning emissions constrained by satellite observations, J. Geophys. Res., 108, 4100, doi:10.1029/2002JD002378, 2003.

Duncan, B. N., Logan, J. A., Bey, I., Megretskaia, I. A., Yantosca, R. M., Novelli, P. C., Jones, N. B., and Rinsland, C. P.: Global budget of CO, 1988-1997: Source estimates and validation with a global model, J. Geophys. Res., 112, D22301, doi:10.1029/2007JD008459, 2007.

Fall, R. and Benson, A. A.: Leaf methanol - The simplest natural product from plants, Trends Plant Sci., 1, 296-301, 1996.

Fehsenfeld, F. C., Ancellet, G., Bates, T. S., Goldstein, A. H., Hardesty, R. M., Honrath, R., Law, K. S., Lewis, A. C., Leaitch, R., McKeen, S., Meagher, J., Parrish, D. D., Pszenny, A. A. P., Russell, P. B., Schlager, H., Seinfeld, J., Talbot, R., and Zbinden, R.: International Consortium for Atmospheric Research on Transport and Transformation (ICARTT): North America to Europe Overview of the 2004 summer field study, J. Geophys. Res., 111, D23S01, doi:10.1029/2006JD007829, 2006.

Galbally, I. E. and Kirstine, W.: The production of methanol by flowering plants and the global cycle of methanol, J. Atmos. Chem., 43, 195-229, 2002.

Goldan, P. D., Trainer, M., Kuster, W. C., Parrish, D. D., Carpenter, J., Roberts, J. M., Yee, J. E., and Fehsenfeld, F. C.: Measurements of hydrocarbons, oxygenated hydrocarbons, carbon monoxide, and nitrogen oxides in an urban Basin in Colorado: Implications for emission inventories, J. Geophys. Res., 100, 
22 771-22 783, 1995a.

Goldan, P. D., Kuster, W. C., Fehsenfeld, F. C., and Montzka, S. A.: Hydrocarbon measurements in the southeastern United States: The Rural Oxidants in the Southern Environment (ROSE) program 1990, J. Geophys. Res., 100, 25 945-25 963, 1995b.

Goode, J. G., Yokelson, R. J., Ward, D. E., Susott, R. A., Babbitt, R. E., Davies, M. A., and Hao, W. M.: Measurements of excess $\mathrm{O}_{3}, \mathrm{CO}_{2}, \mathrm{CO}, \mathrm{CH}_{4}, \mathrm{C}_{2} \mathrm{H}_{4}, \mathrm{C}_{2} \mathrm{H}_{2}, \mathrm{HCN}, \mathrm{NO}, \mathrm{NH}_{3}$, $\mathrm{HCOOH}, \mathrm{CH}_{3} \mathrm{COOH}, \mathrm{HCHO}$, and $\mathrm{CH}_{3} \mathrm{OH}$ in 1997 Alaskan biomass burning plumes by airborne fourier transform infrared spectroscopy (AFTIR), J. Geophys. Res., 105, 22 147-22 166, 2000.

Greenberg, J. P., Friedli, H., Guenther, A. B., Hanson, D., Harley, P., and Karl, T.: Volatile organic emissions from the distillation and pyrolysis of vegetation, Atmos. Chem. Phys., 6, 81-91, 2006, http://www.atmos-chem-phys.net/6/81/2006/.

Griffin, R. J., Chen, J. J., Carmody, K., Vutukuru, S., and Dabdub, D.: Contribution of gas phase oxidation of volatile organic compounds to atmospheric carbon monoxide levels in two areas of the United States, J. Geophys. Res., 112, D10S17, doi:10.1029/2006JD007602, 2007.

Guenther, A., Karl, T., Harley, P., Wiedinmyer, C., Palmer, P. I., and Geron, C.: Estimates of global terrestrial isoprene emissions using MEGAN (Model of Emissions of Gases and Aerosols from Nature), Atmos. Chem. Phys., 6, 3181-3210, 2006, http://www.atmos-chem-phys.net/6/3181/2006/.

Hansen, M. C., DeFries, R. S., Townshend, J. R. G., Carroll, M., Dimiceli, C., and Sohlberg, R. A.: Global percent tree cover at a spatial resolution of 500 meters: First results of the MODIS vegetation continuous fields algorithm, Earth Interactions, 7, 1$15,2003$.

Heikes, B. G., Chang, W. N., Pilson, M. E. Q., Swift, E., Singh, H. B., Guenther, A., Jacob, D. J., Field, B. D., Fall, R., Riemer, D., and Brand, L.: Atmospheric methanol budget and ocean implication, Global Biogeochem. Cy., 16, 1133, doi:10.1029/2002GB001895, 2002.

Holloway, J. S., Jakoubek, R. O., Parrish, D. D., Gerbig, C., VolzThomas, A., Schmitgen, S., Fried, A., Wert, B., Henry, B., and Drummond, J. R.: Airborne intercomparison of vacuum ultraviolet fluorescence and tunable diode laser absorption measurements of tropospheric carbon monoxide, J. Geophys. Res., 105, 24 251-24 261, 2000.

Holzinger, R., Warneke, C., Hansel, A., Jordan, A., Lindinger, W., Scharffe, D. H., Schade, G., and Crutzen, P. J.: Biomass burning as a source of formaldehyde, acetaldehyde, methanol, acetone, acetonitrile, and hydrogen cyanide, Geophys. Res. Lett., 26, 1161-1164, 1999.

Holzinger, R., Jordan, A., Hansel, A., and Lindinger, W.: Methanol measurements in the lower troposphere near Innsbruck $\left(047^{\circ} 16^{\prime} \mathrm{N}\right.$; $\left.011^{\circ} 24^{\prime} \mathrm{E}\right)$, Austria, Atmos. Environ., 35, 25252532, 2001.

Howard, P. H.: Handbook of Environmental Fate and Exposure Data for Organic Chemicals, Volume II - Solvents, CRC Press, New York, 1990.

Hudman, R. C., Jacob, D. J., Turquety, S., Leibensperger, E. M., Murray, L. T., Wu, S., Gilliland, A. B., Avery, M., Bertram, T. H., Brune, W., Cohen, R. C., Dibb, J. E., Flocke, F. M., Fried, A., Holloway, J., Neuman, J. A., Orville, R., Perring, A., Ren, X., Sachse, G. W., Singh, H. B., Swanson, A., and Wooldridge, P. J.:
Surface and lightning sources of nitrogen oxides over the Unites States: Magnitudes, chemical evolution, and outflow, J. Geophys. Res., 112, D12S05, doi:10.1029/2006JD007912, 2007.

Hudman, R. C., Murray, L. T., Jacob, D. J., Millet, D. B., Turquety, S., Wu, S., Blake, D. R., Goldstein, A. H., Holloway, J., and Sachse, G. W.: Biogenic vs. anthropogenic sources of CO over the United States, Geophys. Res. Lett., 35, L04801, doi:10.1029/2007GL032393, 2008.

Jacob, D. J., Field, B. D., Li, Q. B., Blake, D. R., de Gouw, J., Warneke, C., Hansel, A., Wisthaler, A., Singh, H. B., and Guenther, A.: Global budget of methanol: Constraints from atmospheric observations, J. Geophys. Res., 110, D08303, doi:10.1029/2004JD005172, 2005.

Karl, T., Guenther, A., Jordan, A., Fall, R., and Lindinger, W.: Eddy covariance measurement of biogenic oxygenated VOC emissions from hay harvesting, Atmos. Environ., 35, 491-495, 2001 a.

Karl, T., Guenther, A., Lindinger, C., Jordan, A., Fall, R., and Lindinger, W.: Eddy covariance measurements of oxygenated volatile organic compound fluxes from crop harvesting using a redesigned proton-transfer-reaction mass spectrometer, J. Geophys. Res., 106, 24 157-24 167, $2001 \mathrm{~b}$.

Karl, T., Guenther, A., Spirig, C., Hansel, A., and Fall, R.: Seasonal variation of biogenic VOC emissions above a mixed hardwood forest in northern Michigan, Geophys. Res. Lett., 30, 2186, doi:10.1029/2003GL018432, 2003.

Karl, T., Potosnak, M., Guenther, A., Clark, D., Walker, J., Herrick, J. D., and Geron, C.: Exchange processes of volatile organic compounds above a tropical rain forest: Implications for modeling tropospheric chemistry above dense vegetation, J. Geophys. Res., 109, D18306, doi:10.1029/2004JD004738, 2004.

Karl, T., Harren, F., Warneke, C., de Gouw, J., Grayless, C., and Fall, R.: Senescing grass crops as regional sources of reactive volatile organic compounds, J. Geophys. Res., 110, D15302, doi:10.1029/2005JD005777, 2005a.

Karl, T., Harley, P., Guenther, A., Rasmussen, R., Baker, B., Jardine, K., and Nemitz, E.: The bi-directional exchange of oxygenated VOCs between a loblolly pine (Pinus taeda) plantation and the atmosphere, Atmos. Chem. Phys., 5, 3015-3031, 2005b, http://www.atmos-chem-phys.net/5/3015/2005/.

Karl, T., Guenther, A., Jobson, T., Velasco, E., and Lamb, B.: Top-down constraints of volatile organic compound (VOC) emissions, Eos Trans. AGU, 88, Fall Meet. Suppl., Abstract A13I-01, 2007a.

Karl, T., Guenther, A., Yokelson, R. J., Greenberg, J., Potosnak, M., Blake, D. R., and Artaxo, P.: The tropical forest and fire emissions experiment: Emission, chemistry, and transport of biogenic volatile organic compounds in the lower atmosphere over Amazonia, J. Geophys. Res., 112, D18302, doi:10.1029/2007JD008539, 2007b.

Kesselmeier, J., Kuhn, U., Rottenberger, S., Biesenthal, T., Wolf, A., Schebeske, G., Andreae, M. O., Ciccioli, P., Brancaleoni, E., Frattoni, M., Oliva, S. T., Botelho, M. L., Silva, C. M. A., and Tavares, T. M.: Concentrations and species composition of atmospheric volatile organic compounds (VOCs) as observed during the wet and dry season in Rondonia (Amazonia), J. Geophys. Res., 107, 8053, doi:10.1029/2000JD000267, 2002.

Kinnee, E., Geron, C., and Pierce, T.: United States land use inventory for estimating biogenic ozone precursor emissions, Ecol. Appl., 7, 46-58, 1997. 
Lelieveld, J., Berresheim, H., Borrmann, S., Crutzen, P. J., Dentener, F. J., Fischer, H., Feichter, J., Flatau, P. J., Heland, J., Holzinger, R., Korrmann, R., Lawrence, M. G., Levin, Z., Markowicz, K. M., Mihalopoulos, N., Minikin, A., Ramanathan, V., de Reus, M., Roelofs, G. J., Scheeren, H. A., Sciare, J., Schlager, H., Schultz, M., Siegmund, P., Steil, B., Stephanou, E. G., Stier, P., Traub, M., Warneke, C., Williams, J., and Ziereis, H.: Global air pollution crossroads over the Mediterranean, Science, 298, 794-799, 2002.

Liss, P. S. and Slater, P. G.: Flux of gases across air-sea interface, Nature, 247, 181-184, 1974.

Macdonald, R. C. and Fall, R.: Detection of substantial emissions of methanol from plants to the atmosphere, Atmos. Environ., 27, 1709-1713, 1993.

Madronich, S. and Calvert, J. G.: Permutation reactions of organic peroxy radicals in the troposphere, J. Geophys. Res., 95, 5697$5715,1990$.

Mao, H., Talbot, R., Nielsen, C., and Sive, B.: Controls on methanol and acetone in marine and continental atmospheres, Geophys. Res. Lett., 33, L02803, doi:10.1029/2005GL024810, 2006.

McKenzie, L. M., Hao, W. M., Richards, G. N., and Ward, D. E.: Quantification of major components emitted from smoldering combustion of wood, Atmos. Environ., 28, 3285-3292, 1994.

Millet, D. B., Goldstein, A. H., Allan, J. D., Bates, T. S., Boudries, H., Bower, K. N., Coe, H., Ma, Y., McKay, M., Quinn, P. K., Sullivan, A., Weber, R. J., and Worsnop, D. R.: Volatile organic compound measurements at Trinidad Head, California during ITCT 2K2: Analysis of sources, atmospheric composition and aerosol residence times, J. Geophys. Res., 109, D23S16, doi:10.1029/2003JD004026, 2004.

Millet, D. B., Donahue, N. M., Pandis, S. N., Polidori, A., Stanier, C. O., Turpin, B. J., and Goldstein, A. H.: Atmospheric volatile organic compound measurements during the Pittsburgh Air Quality Study: Results, interpretation and quantification of primary and secondary contributions, J. Geophys. Res., 110, D07S07, doi:10.1029/2004JD004601, 2005.

Millet, D. B., Jacob, D. J., Turquety, S., Hudman, R. C., Wu, S., Fried, A., Walega, J., Heikes, B. G., Blake, D. R., Singh, H. B., Anderson, B. E., and Clarke, A. D.: Formaldehyde distribution over North America: Implications for satellite retrievals of formaldehyde columns and isoprene emission, J. Geophys. Res., 111, D24S02, doi:10.1029/2005JD006853, 2006a.

Millet, D. B., Goldstein, A. H., Holzinger, R., Williams, B. J., Allan, J. D., Jimenez, J. L., Worsnop, D. R., Roberts, J. M., White, A. B., Hudman, R. C., Bertschi, I. T., and Stohl, A.: Chemical characteristics of North American surface layer outflow: Insights from Chebogue Point, Nova Scotia, J. Geophys. Res., 111, D23S53, doi:10.1029/2006JD007287, 2006b.

Millet, D. B., Jacob, D. J., Fu, T.-M., Kurosu, T. P., Chance, K., Heald, C. L., and Guenther, A.: Spatial distribution of isoprene emissions from North America derived from formaldehyde column measurements by the OMI satellite sensor, J. Geophys. Res., D02307, doi:10.1029/2007JD008950, 2008.

Nemecek-Marshall, M., Macdonald, R. C., Franzen, F. J., Wojciechowski, C. L., and Fall, R.: Methanol emission from leaves - Enzymatic detection of gas-phase methanol and relation of methanol fluxes to stomatal conductance and leaf development, Plant Physiol., 108, 1359-1368, 1995.

Nightingale, P. D., Malin, G., Law, C. S., Watson, A. J., Liss, P. S.,
Liddicoat, M. I., Boutin, J., and Upstill-Goddard, R. C.: In situ evaluation of air-sea gas exchange parameterizations using novel conservative and volatile tracers, Global Biogeochem. Cy., 14, 373-387, 2000.

Olivier, J. G. J., Bouwman, A. F., Vandermaas, C. W. M., and Berdowski, J. J. M.: Emission Database for Global Atmospheric Research (EDGAR), Environ. Monit. Assess., 31, 93-106, 1994.

Olson, D. M., Dinerstein, E., Wikramanayake, E. D., Burgess, N. D., Powell, G. V. N., Underwood, E. C., D’Amico, J. A., Itoua, I., Strand, H. E., Morrison, J. C., Loucks, C. J., Allnutt, T. F., Ricketts, T. H., Kura, Y., Lamoreux, J. F., Wettengel, W. W., Hedao, P., and Kassem, K. R.: Terrestrial ecoregions of the worlds: A new map of life on Earth, Bioscience, 51, 933-938, 2001.

Organics Over the Ocean Modifying Particles in both Hemispheres: http://www.atmosphere.mpg.de/enid/OOMPH, last access: 28 November 2007.

Parrish, D. D., Kondo, Y., Cooper, O. R., Brock, C. A., Jaffe, D. A., Trainer, M., Ogawa, T., Hubler, G., and Fehsenfeld, F. C.: Intercontinental Transport and Chemical Transformation 2002 (ITCT 2K2) and Pacific Exploration of Asian Continental Emission (PEACE) experiments: An overview of the 2002 winter and spring intensives, J. Geophys. Res., 109, D23S01, doi:10.1029/2004JD004980, 2004.

Parrish, D. D.: Critical evaluation of US on-road vehicle emission inventories, Atmos. Environ., 40, 2288-2300, 2006.

Pfister, G., Hess, P. G., Emmons, L. K., Lamarque, J. F., Wiedinmyer, C., Edwards, D. P., Petron, G., Gille, J. C., and Sachse, G. W.: Quantifying CO emissions from the 2004 Alaskan wildfires using MOPITT CO data, Geophys. Res. Lett., 32, L11809, doi:10.1029/2005GL022995, 2005.

Potter, C. S., Randerson, J. T., Field, C. B., Matson, P. A., Vitousek, P. M., Mooney, H. A., and Klooster, S. A.: Terrestrial ecosystem production: A process model based on global satellite and surface data, Global Biogeochem. Cy., 7, 811-841, 1993.

Randerson, J. T., Thompson, M. V., Conway, T. J., Fung, I. Y., and Field, C. B.: The contribution of terrestrial sources and sinks to trends in the seasonal cycle of atmospheric carbon dioxide, Global Biogeochem. Cy., 11, 535-560, 1997.

Ren, X., Olson, J. R., Crawford, J. H., Brune, W. H., Mao, J., Long, R. B., Chen, Z., Chen, G., Avery, M. A., Sachse, G. W., Barrick, J. D., Diskin, G. S., Huey, L. G., Fried, A., Cohen, R. C., Heikes, B., Wennberg, P. O., Singh, H. B., Blake, D. R., and Shetter, R. E.: $\mathrm{HO}_{\mathrm{x}}$ chemistry during INTEX-A 2004: Observation, model calculation and comparison with previous studies, J. Geophys. Res., 113, D05310, doi:10.1029/2007JD009166, 2008.

Riemer, D., Pos, W., Milne, P., Farmer, C., Zika, R., Apel, E., Olszyna, K., Kliendienst, T., Lonneman, W., Bertman, S., Shepson, P., and Starn, T.: Observations of nonmethane hydrocarbons and oxygenated volatile organic compounds at a rural site in the southeastern United States, J. Geophys. Res., 103, $28111-$ $28128,1998$.

Sachse, G. W., Hill, G. F., Wade, L. O., and Perry, M. G.: Fastresponse, high-precision carbon monoxide sensor using a tunable diode-laser absorption technique, J. Geophys. Res., 92, 20712081, 1987.

Sander, S. P., Friedl, R. R., Golden, D. M., Kurylo, M. J., Moortgat, G. K., Wine, P. H., Ravishankara, A. R., Kolb, C. E., Molina, M. J., Finlayson-Pitts, B. J., Huie, R. E., and Orkin, V. L.: Chemical kinetics and photochemical data for use in atmospheric studies: 
Evaluation number 15, JPL Publication 02-25, Jet Propulsion Laboratory, Pasadena, 2006.

Schade, G. W. and Goldstein, A. H.: Fluxes of oxygenated volatile organic compounds from a ponderosa pine plantation, J. Geophys. Res., 106, 3111-3123, 2001.

Schade, G. W. and Custer, T. G.: OVOC emissions from agricultural soil in northern Germany during the 2003 European heat wave, Atmos. Environ., 38, 6105-6114, 2004.

Schade, G. W. and Goldstein, A. H.: Seasonal measurements of acetone and methanol: Abundances and implications for atmospheric budgets, Global Biogeochem. Cy., 20, GB1011, doi:10.1029/2005GB002566, 2006.

Singh, H., Chen, Y., Tabazadeh, A., Fukui, Y., Bey, I., Yantosca, R., Jacob, D., Arnold, F., Wohlfrom, K., Atlas, E., Flocke, F., Blake, D., Blake, N., Heikes, B., Snow, J., Talbot, R., Gregory, G., Sachse, G., Vay, S., and Kondo, Y.: Distribution and fate of selected oxygenated organic species in the troposphere and lower stratosphere over the Atlantic, J. Geophys. Res., 105, 3795-3805, 2000.

Singh, H., Chen, Y., Staudt, A., Jacob, D., Blake, D., Heikes, B., and Snow, J.: Evidence from the Pacific troposphere for large global sources of oxygenated organic compounds, Nature, 410, 1078-1081, 2001.

Singh, H. B., Tabazadeh, A., Evans, M. J., Field, B. D., Jacob, D. J., Sachse, G., Crawford, J. H., Shetter, R., and Brune, W. H.: Oxygenated volatile organic chemicals in the oceans: Inferences and implications based on atmospheric observations and air-sea exchange models, Geophys. Res. Lett., 30, 1862, doi:10.1029/2003GL017933, 2003.

Singh, H. B., Salas, L. J., Chatfield, R. B., Czech, E., Fried, A., Walega, J., Evans, M. J., Field, B. D., Jacob, D. J., Blake, D., Heikes, B., Talbot, R., Sachse, G., Crawford, J. H., Avery, M. A., Sandholm, S., and Fuelberg, H.: Analysis of the atmospheric distribution, sources, and sinks of oxygenated volatile organic chemicals based on measurements over the Pacific during TRACE-P, J. Geophys. Res., 109, D15S07, doi:10.1029/2003JD003883, 2004.

Singh, H. B., Brune, W. H., Crawford, J. H., Jacob, D. J., and Russell, P. B.: Overview of the summer 2004 intercontinental chemical transport experiment - North America (INTEX-A), J. Geophys. Res., 111, D24S01, doi:10.1029/2006JD007905, 2006.

Singh, H. B., Apel, E., Brune, W., Carmichael, G., Cohen, R., Crawford, J., Czech, E., Emmons, L., Flocke, F., Fried, A., Fuelberg, H., Heikes, B., Jacob, D., and Pierce, B.: A brief overview of INTEX-B and OVOC observations over Mexico City, Gulf of Mexico, and the Pacific Ocean, Eos Trans. AGU, 88, Fall Meet. Suppl., Abstract A42A-01, 2007.

Sinha, P., Hobbs, P. V., Yokelson, R. J., Blake, D. R., Gao, S., and Kirchstetter, T. W.: Emissions from miombo woodland and dambo grassland savanna fires, J. Geophys. Res., 109, D11305, doi:10.1029/2004JD004521, 2004.

Sinha, V., Williams, J., Meyerhofer, M., Riebesell, U., Paulino, A. I., and Larsen, A.: Air-sea fluxes of methanol, acetone, acetaldehyde, isoprene and DMS from a Norwegian fjord following a phytoplankton bloom in a mesocosm experiment, Atmos. Chem. Phys., 7, 739-755, 2007,

http://www.atmos-chem-phys.net/7/739/2007/.

Snider, J. R. and Dawson, G. A.: Tropospheric light alcohols, carbonyls, and acetonitrile: Concentrations in the southwestern
United States and Henry's law data, J. Geophys. Res., 90, 37973805, 1985.

Tabazadeh, A., Yokelson, R. J., Singh, H. B., Hobbs, P. V., Crawford, J. H., and Iraci, L. T.: Heterogeneous chemistry involving methanol in tropospheric clouds, Geophys. Res. Lett., 31, L06114, doi:10.1029/2003GL018775, 2004.

Talbot, R., Mao, H. T., and Sive, B.: Diurnal characteristics of surface level O3 and other important trace gases in New England, J. Geophys. Res., 110, D09307, doi:10.1029/2004JD005449, 2005.

Thompson, A. M., Stone, J. B., Witte, J. C., Miller, S. K., Oltmans, S. J., Kucsera, T. L., Ross, K. L., Pickering, K. E., Merrill, J. T., Forbes, G., Tarasick, D. W., Joseph, E., Schmidlin, F. J., McMillan, W. W., Warner, J., Hintsa, E. J., and Johnson, J. E.: Intercontinental Chemical Transport Experiment Ozonesonde Network Study (IONS) 2004: 2. Tropospheric ozone budgets and variability over northeastern North America, J. Geophys. Res., 112, D12S13, doi:10.1029/2006JD007670, 2007.

Tie, X., Guenther, A., and Holland, E.: Biogenic methanol and its impacts on tropospheric oxidants, Geophys. Res. Lett., 30, 1881, doi:10.1029/2003GL017167, 2003.

Tyndall, G. S., Cox, R. A., Granier, C., Lesclaux, R., Moortgat, G. K., Pilling, M. J., Ravishankara, A. R., and Wallington, T. J.: Atmospheric chemistry of small organic peroxy radicals, J. Geophys. Res., 106, 12 157-12 182, 2001.

von Kuhlmann, R., Lawrence, M. G., Crutzen, P. J., and Rasch, P. J.: A model for studies of tropospheric ozone and nonmethane hydrocarbons: Model description and ozone results, J. Geophys. Res., 108, 4294, doi:10.1029/2002JD002893, 2003a.

von Kuhlmann, R., Lawrence, M. G., Crutzen, P. J., and Rasch, P. J.: A model for studies of tropospheric ozone and nonmethane hydrocarbons: Model evaluation of ozone-related species, J. Geophys. Res., 108, 4729, doi:10.1029/2002JD003348, 2003 b.

Warneke, C., Karl, T., Judmaier, H., Hansel, A., Jordan, A., Lindinger, W., and Crutzen, P. J.: Acetone, methanol, and other partially oxidized volatile organic emissions from dead plant matter by abiological processes: Significance for atmospheric $\mathrm{HO}_{\mathrm{x}}$ chemistry, Global Biogeochem. Cy., 13, 9-17, 1999.

Warneke, C., Luxembourg, S. L., de Gouw, J. A., Rinne, H. J. I., Guenther, A. B., and Fall, R.: Disjunct eddy covariance measurements of oxygenated volatile organic compounds fluxes from an alfalfa field before and after cutting, J. Geophys. Res., 107, 4067, 10.1029/2001JD000594, 2002.

Warneke, C., de Gouw, J. A., Goldan, P. D., Kuster, W. C., Williams, E. J., Lerner, B. M., Jakoubek, R., Brown, S. S., Stark, H., Aldener, M., Ravishankara, A. R., Roberts, J. M., Marchewka, M., Bertman, S., Sueper, D. T., McKeen, S. A., Meagher, J. F., and Fehsenfeld, F. C.: Comparison of daytime and nighttime oxidation of biogenic and anthropogenic VOCs along the New England coast in summer during New England Air Quality Study 2002, J. Geophys. Res., 109, D10309, doi:10.1029/2003JD004424, 2004.

Warneke, C., de Gouw, J. A., Stohl, A., Cooper, O. R., Goldan, P. D., Kuster, W. C., Holloway, J. S., Williams, E. J., Lerner, B. M., McKeen, S. A., Trainer, M., Fehsenfeld, F. C., Atlas, E. L., Donnelly, S. G., Stroud, V., Lueb, A., and Kato, S.: Biomass burning and anthropogenic sources of CO over New England in the summer 2004, J. Geophys. Res., 111, D23S15, doi:10.1029/2005JD006878, 2006.

Warneke, C., McKeen, S., de Gouw, J. A., Del Negro, L., Brioude, 
J., Stark, H., Trainer, M. K., Fehsenfeld, F. C., Wiedinmyer, C., Vanchindorj, U., and Guenther, A. B.: Determination of biogenic emissions from aircraft measurements during TEXAQS2006 and ICARTT2004 campaigns and comparison with biogenic emission inventories, Eos Trans. AGU, 88, Fall Meet. Suppl., Abstract A41D-05, 2007a.

Warneke, C., McKeen, S. A., de Gouw, J. A., Goldan, P. D., Kuster, W. C., Holloway, J. S., Williams, E. J., Lerner, B. M., Parrish, D. D., Trainer, M., Fehsenfeld, F. C., Kato, S., Atlas, E. L., Baker, A., and Blake, D. R.: Determination of urban volatile organic compound emission ratios and comparison with an emissions database, J. Geophys. Res., 112, D10S47, doi:10.1029/2006JD007930, 2007b.

Wesely, M. L.: Parameterization of surface resistances to gaseous dry deposition in regional-scale numerical models, Atmos. Environ., 23, 1293-1304, 1989.

Williams, J., Poschl, U., Crutzen, P. J., Hansel, A., Holzinger, R., Warneke, C., Lindinger, W., and Lelieveld, J.: An atmospheric chemistry interpretation of mass scans obtained from a proton transfer mass spectrometer flown over the tropical rainforest of Surinam, J. Atmos. Chem., 38, 133-166, 2001.
Williams, J., Holzinger, R., Gros, V., Xu, X., Atlas, E., and Wallace, D. W. R.: Measurements of organic species in air and seawater from the tropical Atlantic, Geophys. Res. Lett., 31, L23S06, doi:10.1029/2004GL020012, 2004.

Xiao, Y. P., Jacob, D. J., and Turquety, S.: Atmospheric acetylene and its relationship with $\mathrm{CO}$ as an indicator of air mass age, J. Geophys. Res., 112, D12305, doi:10.1029/2006JD008268, 2007.

Yevich, R. and Logan, J. A.: An assessment of biofuel use and burning of agricultural waste in the developing world, Global Biogeochem. Cy., 17, 1095, doi:10.1029/2002GB001952, 2003.

Yokelson, R. J., Bertschi, I. T., Christian, T. J., Hobbs, P. V., Ward, D. E., and Hao, W. M.: Trace gas measurements in nascent, aged, and cloud-processed smoke from African savanna fires by airborne Fourier transform infrared spectroscopy (AFTIR), J. Geophys. Res., 108, 8478, doi:10.1029/2002JD002322, 2003. 